\title{
METAPHOR, OBJECTS, AND COMMODITIES
}

\author{
GEORGE H. TAYLOR ${ }^{*} \&$ MichAEL J. MADISON ${ }^{* *}$
}

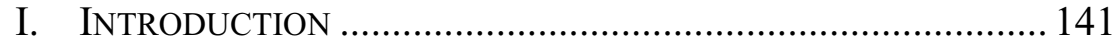

II. OBJECTIFICATION VERSUS REIFICATION............................. 142

III. TOWARD AN ACCOUNT OF OBJECTIFICATION

AND BOUNDARIES ........................................................ 157

A. On Metaphor and Language ...................................... 159

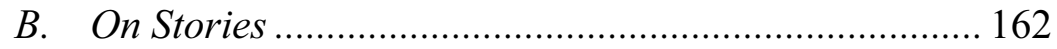

C. On Objects ............................................................ 165

D. On Place and Space................................................. 168

E. On Convention, Pattern, and Practice ...................... 170

IV. CONCLUSION................................................................. 173

\section{INTRODUCTION}

At a faculty lunch a couple of years ago, one of us, a teacher of Property and a student of metaphor and the hermeneutics of Paul Ricoeur, heard the other, a scholar specializing in intellectual property, describe a paper about "things." Conversations ensued, drafts were exchanged, comments were discussed, and a productive dialogue emerged. That dialogue has matured into this Comment. It seems altogether fitting that our discussion is honed and framed by the work of Margaret Jane Radin, whose signal work on commodification and objectification in law has proved so thoughtprovoking.

We begin in considerable sympathy with Radin's relational approach to property. In somewhat differing ways, we each relate this relational approach to its beginnings in metaphor and the central organizing value that metaphor has in producing knowledge. We take our cue from Radin's work, but like others, we intend to take the commodification/objectification inquiry in some new directions, exploring both the ongoing potential of metaphor to illuminate both questions of theory and doctrine, and how various ways of thinking about commodification and objectification can - in the words of Radin's contribution to this Symposium - help us to situate the "neighborhood" of property law in a city of diverse and interdependent communities. ${ }^{2}$

As its two main Parts will evidence, this Comment remains the product of two distinct if overlapping voices. Part II returns to the conceptual origins of Radin's theory in her general critique of objectification and commodification. It asks

*Associate Professor, University of Pittsburgh School of Law.

${ }^{* *}$ Associate Professor, University of Pittsburgh School of Law.

${ }^{1}$ Michael J. Madison, Law as Design: Objects, Concepts, and Digital Things, CASE W. RES. L. REV. (forthcoming 2006) [hereinafter Madison, Law as Design].

${ }^{2}$ Margaret Jane Radin, A Comment on Information Propertization and its Legal Milieu, 54 Clev. ST. L. REv.23 (2006) [hereinafter Radin, Information Propertization]. 
whether a more positive concept of objectification can be recovered that is distinguishable from reification, the latter seeming to be the more appropriate locus of Radin's criticism. Part III's response to Radin is similar, but it tries to exemplify both our appreciation of and our differences from her work through more detailed analysis of intellectual property law and theory.

\section{OBJECTIFICATION VERSUS REIFICATION}

As her article in this Symposium aptly confirms, ${ }^{3}$ Margaret Radin has contributed significantly to a relational view of property. We derive from this relational approach two larger themes. First, within the legal neighborhood of propertization, ${ }^{4}$ the character of an item as property is not determined by the item in isolation but in weighing and balancing the relations between those who assert to control it and those who seek to freely use it. ${ }^{5}$ Further, this balancing is reassessed in its relation to new points of application. ${ }^{6}$ Second and correlatively, propertized items are never simply brute facts whose legal character derives from this facticity. Instead, their "facticity" is intertwined with their legal character, with the policy judgment that balances the interests at stake. As Radin writes, "[F]acts are not 'out there' waiting to be described by a discourse. Facts are theory-dependent and value-dependent." The relational nature of property and its interrelation of fact and theory are especially evident in the changes to property doctrine over time as it is applied to changing circumstances. $^{8}$ As Radin discusses ${ }^{9}$ and as we shall later probe at greater length, ${ }^{10}$ this is particularly apparent as the law attempts to deal with new forms of digital information. Old categories are breaking down, and a reconceptualization appears to be in progress. ${ }^{11}$

We want to support and deepen Radin's analysis here by drawing upon the insights of philosopher Paul Ricoeur. As to the interrelation of theory and fact, Ricoeur affirms that it is impossible to separate the two: a "fact" is always interwoven with our conceptualization of it. "The so-called 'real' process [of human life and activity]," Ricoeur maintains, "already has a symbolic dimension. . . . [A]

\footnotetext{
${ }^{3}$ See id.

${ }^{4} I d$.

${ }^{5}$ Id. at 25-27; see also CAROL M. Rose, Property as Storytelling: Perspectives from Game Theory, Narrative Theory, Feminist Theory, in PROPERTY AND PERSUASION 27-28 (1994) [hereinafter Rose, Property as Storytelling] ("We often think of property as some version of entitlement to things: I have a right to this thing or that. In a more sophisticated version of property, of course, we see property as a way of defining our relationships with other people.").

${ }^{6}$ See, e.g., Margaret Jane Radin, Property Evolving in Cyberspace, 15 J.L. \& CoM. 509 (1996) [hereinafter Radin, Property Evolving].

${ }^{7}$ Margaret Jane Radin, Contested Commodities 89 (1996).

${ }^{8}$ Radin, Information Propertization, supra note 2, at 26

${ }^{9}$ See, e.g., Radin, Property Evolving, supra note 6.

${ }^{10}$ See discussion infra Part III.

${ }^{11}$ Margaret Jane Radin, Information Tangibility, in ECONOMICS, LAW AND INTELLECTUAL Property 395, 405 (Ove Granstrand ed., 2003).
} 
presymbolic ... stage of real life can nowhere be found. Symbolism in general is not a secondary effect of social real life; it constitutes real life as socially meaningful. . . . . [T] he symbolic function is originary . . .."12 Elsewhere Ricoeur insists that "symbolic systems belong already to the infrastructure, to the basic constitution of human being." 13 Human life is symbolically mediated; it is caught in an inextricable interpretive web; fact cannot be separated from symbolization.

A second insight we draw from Ricoeur by way of his heremeneutic predecessor, Hans-Georg Gadamer. This point deepens Radin's argument that property doctrine changes as it is applied in new contexts. Gadamer famously contends that meaning and application are interrelated: the meaning of a principle is not determined at the outset for all time but changes as it is applied in new circumstances. As Gadamer argues, application involves "co-determining, supplementing, and correcting [a] principle." 14 Commentator Joel Weinsheimer clarifies that this means that neither the interpretive rule "nor the instance to which it is applied is antecedent to the other"; their relationship is "reciprocal rather than unilateral. Each term modifies and acts on the other so that they interact." 15 We emphasize here the relational nature of meaning: at the point of application, existing categorization may be broken and reformed. Following Ricoeur, we also characterize the nature of meaning here as metaphoric. Metaphor violates a current order; it transgresses the given order. ${ }^{16}$ The new circumstance cannot be accommodated without change and so disrupts existing doctrine or principles. Metaphor does not just disorder, though; the process of metaphoric as-similation leads to the creation of a new ordering, a transfiguration of prior doctrine or principles. ${ }^{17}$ The relational nature of this metaphoric operation deserves emphasis: metaphor involves not just a word "whose meaning is displaced, but the pair of terms or relationships between which the transposition operates."18 Ricoeur underscores how basic this metaphoric operation may be:

${ }^{12}$ Paul Ricoeur, Can There be a Scientific Concept of Ideology?, in PHENOMENOLOGY AND THE SOCIAL SCIENCES 44, 51 (Joseph Bien ed., 1978).

${ }^{13}$ Paul Ricoeur, Lectures on IdeOlogy And Utopia 258 (George H. Taylor ed., 1986) [hereinafter RiCOEUR, LECTURES]. The reference to the symbolic as infrastructural here is an explicit challenge to Marxian orthodoxy where the infrastructure - the basic activity of human life - is economic and the symbolic or ideational (which would include law) is merely superstructural, that is, derivative from the economic. See id. at 153-54.

${ }^{14}$ Hans-Georg Gadamer, Truth and Method 39 (1992). For Gadamer, law is a primary exemplification of this interrelation. See id. at 324-41.

${ }^{15}$ Joel Weinsheimer, Philosophical Hermeneutics AND Literary THEORY 80 (1991); see also JOEL WeINSHEIMER, GADAMER's HERMENEUTICS: A READING OF TRUTH AND METHOD 192 (1985) ("[T]he general is . . continually determined by the particular, even as it determines the particular. Application is not reductive but productive ....").

${ }^{16}$ See Paul Ricoeur, The Rule of Metaphor 21-22 (Robert Czerny trans., 1977) [hereinafter RICOEUR, METAPHOR]. This characterization of metaphor as disruptive is quite different from other contemporary theories that emphasize the continuity of metaphor from source to target domain. See, e.g., GeORge LAKOFF \& MARK Johnson, Philosophy In The Flesh: The Embodied Mind and its Challenge to Western Thought (1999).

${ }^{17}$ Ricoeur, MEtAPHOR, supra note 16 , at 22.

${ }^{18} I d$. at 21 (emphasis omitted). 
[C]ould we not imagine that the process that disturbs and displaces a certain logical order, a certain conceptual hierarchy, a certain classification scheme, is the same as that from which all classification proceeds? ... [C]ould we not imagine that the order itself is born in the same way that it changes? Is there not, in Gadamer's terms, a 'metaphoric' at work at the origin of logical thought, at the root of all classification? ... The idea of an initial metaphorical impulse destroys the[] oppositions between proper and figurative, ordinary and strange, order and transgression. It suggests the idea that order itself proceeds from the metaphorical constitution of semantic fields, which themselves give rise to genus and species. ${ }^{19}$

The literal exists within the wider and deeper context of metaphor. The literal is not originary but simply current or usual meaning, ${ }^{20}$ meaning that can be transformed by metaphoric means in the application to new circumstances.

We would join the symbolic mediation of life discussed earlier with the categorial priority granted metaphor here. Both are elements of a larger metaphoric: facts do not exist independent of theorization or conceptualization; categorization rests upon a metaphoric impulse. Radin seems to agree: "In one sense, there cannot be any sharp divide between the literal and the metaphorical, because there is no sharp divide between action and discourse - between the nature of a transaction and the conceptual scheme or discursive framework in which we understand it." ${ }^{21}$ Metaphor is originary, inextricable, and relational. Recognition of the originary role played by metaphor in conceptualization and categorization, we argue, provides more substantial support for a relational theory of property.

Thus far, our argument has been consistent with Radin's. There is a side of Ricoeur's analysis of interpretation other than the metaphoric, however, and elucidation of that perspective will start to move us away from Radin. Having established the common grounds between us and Radin, we can now begin to demarcate our differences, a project that will consume the remainder of our Comment.

Ricoeur argues that interpretation "functions at the intersection of two domains, metaphorical and speculative." ${ }^{22}$ Speculative discourse establishes the principles

${ }^{19} I d$. at 22-23 (footnote omitted) (citing HANS-GEORG GADAMER, WARHHEIT UND Methode 71, 406ff (1960) [GADAMER, TRUTH AND Method, supra note 14, at 75, $429 \mathrm{ff}$ ]); see also id. at 24, 197-98.

${ }^{20} I d$. at 290-91. This conception of the literal as the usual allows reconciliation of Ricoeur's approach with Wittgenstein's claim that "there is a way of grasping a rule which is not an interpretation, but which is exhibited in what we call 'obeying the rule' and 'going against it' in actual cases.” Ludwig Wittgenstein, Philosophical InVEstigations pt.I, ๆ 201 (G. E. M. Anscombe trans., 3d ed. 1968). Grasping a rule is not an interpretation to the extent that the usual use of the rule is available rather than needing to be transformed at the point of application. For application of Wittgenstein's approach to law, see FrEDERICK SCHAUER, Playing BY THE RULES (1991).

${ }^{21}$ Radin, Contested Commodities, supra note 7, at 2; see also Rose, Property AND PERSUASION, supra note 5, at 296 (“[S]eeing property is an act of imagination").

${ }^{22}$ Ricoeur, The Rule of MetaPhor, supra note 16, at 303. 
"that articulate primordially the space of the concept." ${ }^{\text {"23 }}$ Whereas the metaphorical domain allows meaning to proliferate at new points of application, speculative discourse is reductive, elucidative; it tries to bring order, establish univocity, derive a concept. ${ }^{24}$ Ricoeur aspires to establish an interpretive method responsive to the interplay between the two domains. He seeks, he says, "a hermeneutic style where interpretation would conform both to the notion of concept and to that of the constitutive intention of the experience seeking to be expressed in the metaphorical mode." 25 In his view, then, interpretation is a "composite discourse" that feels "the opposite pull of two rival demands": the pull on one side toward the concept, the pull on the other of metaphor that "hopes to preserve the dynamism of meaning that the concept holds and pins down." 26

The question we would like to pursue is whether property interpretation-in particular, intellectual property interpretation - can maintain a "composite discourse" responsive to both the metaphoric dynamism of meaning and the conceptual and doctrinal drive toward univocity. We argue that although Radin is certainly attentive to doctrinal needs, her own relational approach to property may weigh too heavily towards the side of metaphor. In particular, while Radin's work is noteworthy and laudable in its efforts to protect personhood - a dynamic of personal meaning - she mistakenly, in our view, maintains that the objectification of personhood or its commodification (a subcategory of the former) leads to personhood's elimination. We endeavor to show that objectification - whether of person or of doctrine-is not only inevitable but potentially positive. In this analysis, objectification stands for the conceptual side of interpretation's composite discourse. In Part III, we turn to intellectual property theory and offer considerable doctrinal development of how treatment of property as thing or object can at the same time preserve the dynamism of meaning on the metaphorical side of interpretation.

Radin is perhaps best known for her argument that certain qualities of personhood should be inalienable in the economic market; to be preserved, they must be protected from market exchange and therefore not be commodified. ${ }^{27}$ Radin originally derived her conception of commodification in significant part from Hegel's Philosophy of Right. ${ }^{28}$ Our own recontextualization of the perspective offered by Radin can be situated by a return to this text. It is not that Radin's own

\footnotetext{
${ }^{23} I d$. at 300 .

${ }^{24} I$. at 302 . In the present context, then, we might describe Radin's original conceptions of commodification as more metaphoric - the promulgation of a new way of thinking - and the second generation of commodification scholarship as one more of speculative discourse, an attempt to think through more critically and analytically what commodification entails. This differentiation is, of course, a generalization and is not intended to demean the analytic power of Radin's argument or the creative, metaphoric side of the new scholarship.

${ }^{25} I d$. at 303 .

${ }^{26} I d$.

${ }^{27}$ See, e.g., RADIN, CONTESTED COMMODITIES, supra note 7, at 16-29.

${ }^{28}$ See, e.g., id. at 35-40 (citing G.W.F. Hegel, Hegel's Philosophy of Right (T. M. Knox trans., 1952)). Radin's earlier work on personhood also draws upon as it differentiates itself from this same text. See, e.g., Margaret Jane Radin, Reinterpreting Property 4448 (1993).
} 
conception rises or falls to the degree it adheres to Hegel; the rigor and depth of her ideas must be assessed on their own terms. But a return to the Philosophy of Right provides a useful entrance to our theme, because more seems relevantly at work in the text than Radin appeared to suppose. In paragraph 43, Hegel asks whether the attainments of the artist, scholar, or preacher - their "art, erudition, ability to preach a sermon," etc.- - are "things."

We may hesitate to call such abilities, attainments, aptitudes, \&c., "things", for while possession of these may be the subject of business dealings and contracts, as if they were things, there is also something inward and mental about it . . . Attainments, erudition, talents, and so forth, are, of course, owned by free mind and are something internal and not external to it, but even so, by expressing them it may embody them in something external and alienate them ... and in this way they are put into the category of "things." 29

We would emphasize in this passage a differentiation between externalization and alienation. As the translator quotes Hegel in a subsequent footnote, "Alienation is giving up something which is my property and which is already external, it is not to externalize." "30 The alienation of property places it into the market, and Radin builds on this in her conception of commodification. In the extended passage above, it is instructive that Hegel is attentive to that which is internal and "owned by free mind"- qualities of personhood that are Radin's concern—but he does not view alienation of these qualities as inherently destructive of them.

We comprehend Hegel's larger themes in the Philosophy of Right if we characterize alienation as a subcategory of externalization. We want to emphasize the role externalization plays in Hegel's analysis, a theme that Radin does not seem sufficiently to attend. For Hegel, externalization is something positive. As the examples of the scholar, artist, and preacher suggest, their will and person are made manifest in externalizations of themselves in their work. Their art, scholarship, and preaching are externalizations or embodiments of themselves. Who we are inwardly needs to be externalized, needs to be expressed outwardly. The embodiment of the will is "an immediate external thing." ${ }^{\text {31 }}$ We must translate our freedom into an

\footnotetext{
${ }^{29}$ G.W.F. Hegel, Hegel's Philosophy of Right q 43 (T. M. Knox trans., 1952) (emphasis added). We do not include in this quotation sections where Hegel seems to equate characterization of something as a "thing" with it having legal status, as the subject of contracts and so on. We return later to criticize this equation: just because something is characterized as a "thing" does not tell us necessarily anything about how it should be conceived legally. That remains an interpretive policy judgment. See infra text accompanying notes 124-25. It is also unclear from Hegel's passage whether something becomes a "thing" because it is externalized or because it is alienated. As we shall discuss, see infra text accompanying notes $31-33,45-46$, we more expansively interpret a "thing" as the product of externalization.

${ }^{30} I d$. at 322 n. 16 (citation omitted).

${ }^{31} I d$. 133 .
} 
"external sphere." ${ }^{\prime 32}$ The interior self becomes realized or actualized by the process of externalization. ${ }^{33}$

By contrast, Radin reads the relation between will and external sphere not as a manifestation of the will in the production of the external but only as the imposition of the will on a pre-existent external world. ${ }^{34}$ For instance, Radin emphasizes Hegel's pronouncement that an individual can alienate - that is, let go of or transfer to another - only a "thing external by nature." 35 While Radin views this category as that of pre-existent natural things, ${ }^{36}$ we understand it to exclude only those personal attributes that cannot be alienated, such as one's ethical life or religion. ${ }^{37}$ Radin concludes that "only objects separate from the self are suitable for alienation," ${ }^{, 38}$ and this leads, she argues, to an untenable distinction between subject and object, between something internal to the person and an external thing - property - that can be manipulated and controlled. ${ }^{39}$ Radin does allow at a couple points that Hegel provides that mental creations are "capable of objectification by being externalized," ${ }^{40}$ but this does not lead her to revise her larger assessment of Hegel. As we shall later discuss, this will have unfortunate repercussions in her discussions of, for example, intellectual property. While Radin acknowledges that mental products can be externalized and hence are "propertizable," they are still, she insists, not things "external by nature." Radin continues: "The picture of intellectual property as an external object becomes more problematic every day, as intellectual property comes to exist in a digital world and is not embodied in any objects we can point to." ${ }^{, 41}$ As we shall argue, the more positive assessment Hegel provides of the externalization of the self into created objects permits a recasting of this problem.

The positive characterization of externalization found in Hegel is also available in the young Marx. Marx goes beyond Hegel in criticizing the alienation of one's labor to the extent that the process and product of labor are not matters of selfexpression but rather imposed on the laborer from outside. ${ }^{42}$ Our more customary

\footnotetext{
${ }^{32} I d$. 41 ("A person must translate his freedom into an external sphere in order to exist as Idea.").

${ }^{33}$ See Ricoeur, LECTURES, supra note 13, at 38-39 (describing the Hegelian approach).

${ }^{34}$ See Radin, Reinterpreting Property, supra note 28, at 45 (citing G.W.F. Hegel, supra note 29, ๆ 41$)$.

${ }^{35} I d$. at 195 (citing G.W.F. Hegel, supra note 29, 65); RADIN, CONTESTED Commodities, supra note 7, at 35 (citing G.W.F. HeGEL, supra note 29, ๆ 65)

${ }^{36}$ See, e.g., RADIN, CONTESTED COMMODITIES, supra note 7, at 35-37.

${ }^{37}$ See G.W.F. HEGEL, supra note 29 , $₫$ 66. These attributes are also discussed by Radin, but she does not draw the same conclusions as do we. See, e.g., Radin, Contested COMMODities, supra note 7, at 35-36.

${ }^{38}$ RAdin, CONTESTED COMMODITIES, supra note 7, at 34.

${ }^{39}$ See id.; Radin, Information Tangibility, supra note 11, at 397.

${ }^{40}$ Radin, Property Evolving, supra note 6, at 511.

${ }^{41}$ RADIN, CONTESTED COMMODITIES, supra note 7, at 38.

${ }^{42}$ See, e.g., Karl Marx, The Economic And Philosophic Manuscripts of 1844, at 111 (Dirk J. Struik ed., 1964) [hereinafter MARX, MANUSCRIPTS].
} 
contemporary sense of the term alienated labor derives from this understanding. Under these conditions, says Marx, "[1]abor produces not only commodities: it produces itself and the worker as a commodity. . . ."43 When Radin discusses Marx as someone totally opposed to commodification,${ }^{44}$ this is the Marx to whom she is referring. This process of externalization is negative because alien. Yet Marx also wants to retain a positive concept of externalization, a process that he calls "objectification." The proper rather than alienated object of labor is "the objectification of man's species life." ${ }^{45}$ As Marx comments in another passage, "[1]abor's realization is its objectification." ${ }^{46}$ This productive capacity of externalization is positive: "[i]t is life-engendering life." 47 This positive capacity of externalization is similar to that in Hegel. For the early Marx, writes Ricoeur, "humanity produces itself . . by objectifying itself." ${ }^{\text {" }}$ It may be that this possibility of objectification will become known historically only after the alienation of labor is eliminated, but, Ricoeur observes, "it is on the assumption of the abolition of estrangement that the fundamental concept of objectification is revealed." 49

Radin addresses the alienating form of labor that Marx described. ${ }^{50}$ "Alienation comes about," she writes, "when attributes of personhood are sundered." objectification describes this negative treatment, where people are treated as means not ends; attributes of the person become objects - commodities - that may be purchased or sold in the economic market. ${ }^{52}$ Because the person is conceived simply as an element of market exchange, commodification reduces the person as subject to a thing, an object. ${ }^{53}$ Throughout her work, Radin admirably wants to analyze how to

\footnotetext{
${ }^{43} I d$. at 107 (emphasis omitted).

${ }^{44}$ See RADIN, CONTESTED COMMODITIES, supra note 7, at xiii (asserting that Marx's theory represents the pole of "universal noncommodification").

${ }^{45}$ MARX, MANUSCRIPTS, supra note 42, at 114 (emphasis omitted).

${ }^{46} I d$. at 108 . He goes on to say that now "[i]n the sphere of political economy this realization of labor appears as loss of realization for the workers; objectification as the loss of the object and bondage to it; appropriation as estrangement, as alienation." Id. (emphasis omitted).

${ }^{47} I d$. at 113 .

${ }^{48}$ See RiCOEUR, LECTURES, supra note 13 , at 44.

${ }^{49} I d$. at 60-61. As over time in his work Marx moves increasingly to invert Hegel's idealism and maintain a more materialist stance, he nevertheless retains a positive, productive sense of human externalization. Ricoeur argues, for instance, that the concept of self-activity discussed in The German Ideology, see, e.g., KARL MARX \& FrEDERICK ENGELS, THE GERMAN IDEOLOGY 92 (C. J. Arthur ed., 1970), preserves from earlier writing "something of the concept of objectification, the self-creation of human being." RICOEUR, LECTURES, supra note 13 , at 99 .

${ }^{50}$ See, e.g., RADIN, REINTERPRETING Property, supra note 28, at 192-93; RADIN, CONTESTED COMMODities, supra note 7, at 80.

${ }^{51}$ RADIN, REINTERPRETING Property, supra note 28, at 193.

${ }^{52}$ RAdin, CONTESTED COMMODITIES, supra note 7, at 156.

${ }^{53}$ Margaret Jane Radin \& Madhavi Sunder, Introduction: The Subject and Object of Commodification, in Rethinking COMMOdifiCATION: CASES AND READINGS IN LAW AND
} 
preserve human personhood from this reduction..$^{54}$ Radin does not argue that marketexchange is inevitably wrong, ${ }^{55}$ and "incomplete commodification" allows that an action can both preserve personhood and also enter the market to a degree. ${ }^{56}$ She also finds available positive notions of work, although they do not derive from Marx. On the one hand, she regards as valuable "the freedom to fuse oneself by one's efforts with the external environment. ${ }^{, 57}$ Note, though, that this is an operation of the self on a pre-existing object, not the externalization that creates an object. On the other hand, she does differentiate between (negative) labor and (positive) work: "Laborers play [musical] notes, we might say, and workers play the music. . . . Money does not ... exhaust the value of [workers'] activity." ${ }^{.58}$ Work is in this sense constitutive of self and person. ${ }^{59}$ This characterization of work would seem consistent with the positive concept of objectification that we propose: an externalization and actualization of oneself in the music, the art, the craft, or potentially many other forms of work. Yet Radin's restrictions on the meanings of objectification and commodification do not permit as positive a subject's objectification in his or her work. Work, Radin writes, always contains a "noncommodified human element." ${ }^{60}$ For us, the issue is not commodification or noncommodification but whether the objectification is positive or not. ${ }^{61}$ Radin by

Culture 8, 8 (Martha M. Ertman \& Joan C. Williams eds., 2005) [hereinafter Radin \& Sunder, The Subject and Object of Commodification].

${ }^{54}$ See, e.g., RADIN, CONTESTED COMMODITIES, supra note 7, at 16-29 (developing the notion of "market-inalienability").

${ }^{55}$ See id. at xii.

${ }^{56} \mathrm{See}$ id. at 20.

${ }^{57}$ See RADIN, REINTERPRETING PROPERTY, supra note 28, at 50.

${ }^{58}$ RAdin, CONTESTED COMMOdities, supra note 7, at 105.

${ }^{59}$ Id.

${ }^{60} I d$. (emphasis added).

${ }^{61}$ This approach seems consistent with and supportive of work by the newer generation of commodification theorists. See, e.g., Martha M. Ertman \& Joan C. Williams, Preface: Freedom, Equality, and the Many Futures of Commodification, in RETHINKING COMmodification: CASES AND READINGS IN LAW AND Culture, supra note 53, at 1, 4 [hereinafter Ertman \& Williams, Preface] ("The new materials in this book, taken as a whole, argue against the vision of a world bifurcated into separate hostile spheres whose boundary is policed by commodification anxiety. In fact, intimate relations typically have economic dimensions, and market relations often do not adhere to the model of self-interest, and selfinterest alone."); see also Carol M. Rose, Afterword: Whither Commodification, in RETHINKING COMMODIFICATION: CASES AND READINGS IN LAW AND CUlTURE, supra note 53, at 402, 412 [hereinafter Rose, Afterword] (arguing that commodification may be "normgenerative" rather than simply "norm-destructive").

In an introductory essay to this volume, Radin demonstrates that she is receptive to this new scholarship. She and co-author Madhavi Sunder write that the questions this new scholarship raises "remind us that the goal is not commodification or noncommodification, per se, but rather . . . a world in which all individuals and groups have rights to make their cultural worlds." Radin \& Sunder, The Subject and Object of Commodification, supra note 53, at 20. Our criticism is that Radin does not fully address this theme in her theory of commodification, 
contrast emphasizes the "personal touch in one's work," 62 the "personal aspect of work," ${ }^{63}$ rather than the personhood achieved in the objectification in the work. At the same time that "our culture persistently commodifies and objectifies," Radin maintains, it also "stubbornly insists on conceiving of the person as moral agent, as humane subject distinct from the world of objects." ${ }^{44}$ Personhood must be protected from objectification. Objectification is the "failure to respect in theory and to make space in practice for the human subject." ${ }^{95}$ Objectification is the negation of the human subject. ${ }^{66}$ Ironically, while Radin criticizes the dualism that splits subject and object, ${ }^{67}$ it is a dualism that in this regard she herself maintains.

We contend, then, that Radin does not maintain a distinction between positive and negative forms of externalization. Rather than concentrate on whether particular types of commodification are good or bad, a more useful distinction may be whether externalization is good or bad. If externalization is good and so a positive form of self-actualization, it should be called objectification. If the externalization is bad in the sense that the human expression in the thing or object is stripped away, then it should be called alienation or reification. ${ }^{68}$ We shall prefer to use the term reification

and we go on to argue that attention to externalization and objectification would help to orient this reconceptualization.

${ }^{62}$ RAdin, CONTESTED COMMODitiEs, supra note 7, at 105 (emphasis added).

${ }^{63} I d$. at 108 (emphasis added).

${ }^{64}$ See, e.g., Margaret Jane Radin, Reflections on Objectification, 65 S. CAL. L. REV. 341, 343 (1991) [hereinafter Radin, Objectification] (emphasis added).

${ }^{65}$ RADIN, CONTESTED COMMODITIES, supra note 7, at 155.

${ }^{66} I d$.

${ }^{67}$ To be precise, Radin maintains that her project blurs the distinction both between subject and object - which "calls to mind the disjunction between persons and things" - and between the subjective and the objective - which "calls to mind the disjunction between what is 'inside' the will of a person . . . and what is 'outside' in the world of objects . . .." RADIN, REINTERPRETING PROPERTY, supra note 28, at 9. As should be apparent, we also attempt to break down both of these distinctions, and we argue Radin maintains an inappropriate division between subject and its objectification in the object.

${ }^{68}$ See, e.g., Paul Ricoeur, Objectivation et Aliénation dans l'Expérience Historique, 45 ARCHIVIO DI FIlOSOFIA 27 (1975) [hereinafter Ricoeur, Objectivation et Aliénation] (developing the distinction between objectification and alienation). Ricoeur here equates alienation with reification. See id. at 32. He also appears to derive the concept of objectification independently from Marx, who is not mentioned in this essay. For further development of the concept of alienation, see Paul Ricoeur, Aliénation, 1 EnCYCLOPAEDIA UNIVERSALIS 660 (1968).

We are aware that the term objectification may have a negative connotation in English, as it does, for instance, in Radin. See, e.g., Radin, Objectification, supra note 64. We retain this term because it is the customary one used in positive contexts in English, see supra text accompanying notes 45-49 (on Marx), and in most translations of Ricoeur's usage of the term. See infra text accompanying notes 77, 79, 81, 83. But the French term "objectivation," see supra, may come closer to disclosing what we are after: a sense of an objectifying process by human activity rather than just the object produced, the objectification. In at least one of his articles, Ricoeur's use of the French term "objectivation" was translated into English by the identical term. See Paul Ricoeur, Philosophical Hermeneutics and Theological Hermeneutics, 
for the negative form of externalization, because the word's etymology (from the Latin res, thing) ${ }^{69}$ underscores the transformation of something into only a thing. Its human and relational qualities are gone. To the extent that Radin concludes that externalization-whether in the form of objectification or its subcategory commodification - is necessarily negative, she seems to be rejecting the relational view of fact and value that she otherwise strongly defends. ${ }^{70}$ Just because something is an object or thing, that "facticity" does not make it negative. Rather, its facticity is value-dependent; ${ }^{71}$ in the present context, the object or thing is negative or positive depending on whether it is a positive externalization or not. In turn, the differentiation between positive and negative externalization rests on appreciation first of the need for and inevitability of externalization of anything internal, and we turn to draw especially on Ricoeur's hermeneutics to develop this understanding.

Ricoeur is sympathetic to Radin's concern for the protection of the inward qualities of personhood. But he insists that we know of these inward qualities by their outward externalizations:

In opposition to . . the claim of the subject to know itself by immediate and direct intuition, we must say that we understand ourselves via the detour of the signs of humanity sedimented in the works of culture. The structure of the work is the tool of this sedimentation and therefore also of this highly mediated mode of transmission. What would we know of love and hatred - and, in general of the feelings and the values which support the Self - if they had not been brought to language and articulated by works of art and discourse? The texture of the text is the bearer of this mediation. $^{72}$

Ricoeur's hermeneutics is predicated upon the claim that we understand the self, others, actions, or history not by intuition but through the marks or signs they display. ${ }^{73}$ These marks or signs are exteriorizations; they are texts and texts that need to be interpreted. The exteriorization of signs-e,g., gestures, dance, language,

5 Studies in Religion Sciences Religieuses 14, 18 (1975-76) (Can.) [hereinafter Ricoeur, Philosophical Hermeneutics].

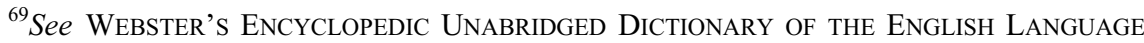
1210 (1994).

${ }^{70}$ See supra text accompanying notes 7-8.

${ }^{71}$ RADin, CONTESTED COMMODITIES, supra note 7, at 89.

${ }^{72}$ Ricoeur, Philosophical Hermeneutics, supra note 68, at 30; see also PAUL RICOEUR, ThE CONFLiCt of InTERPRETATIONS 327 (Don Ihde ed., 1974) ("The first truth-I think, I amremains as abstract and empty as it is unassailable. It must be 'mediated' by representations, actions, works, institutions, and monuments which objectify it . . .") (second emphasis added).

${ }^{73}$ This emphasis in Ricoeur marks a signal departure of his hermeneutics from that of Gadamer's. Gadamer views objectification as necessarily alienating, and he critiques the method of the human sciences as alienating because objectifying. See, e.g., PAUL Ricoeur, The Task of Hermeneutics, in Hermeneutics AND the Human SCIEnCES 43, 60 (John B. Thompson ed. \& trans., 1981) (exploring this distinction); Ricoeur, Philosophical Hermeneutics, supra note 68, at 14. 
and so on ${ }^{74}$-is the first condition for the understanding of another, and these signs are a text that we must interpret. ${ }^{75}$ Writing is possible because discourse itself presents a form of exteriorization that permits its inscription in a material medium. ${ }^{76}$ Action is textual in its objectification or exteriorization that is similar to the fixation that occurs in writing. ${ }^{77}$ Our belonging to traditions must pass through "the interpretation of the signs, works and texts in which cultural heritages are inscribed and offer themselves to be deciphered." 78 Communication of these past heritages therefore occurs under the condition of their objectification. ${ }^{79}$ Radin argues that "it is hard to see our work, either physical or intellectual, as belonging intrinsically . . . to the object realm." ${ }^{\prime 80}$ By contrast, Ricoeur insists that exteriorization or objectification is an ineluctable element of human activity ${ }^{81}$ it is as primitive and radical - that is, to the root-as possible. ${ }^{82}$ The relationship between objectification and interpretation is not dichotomous but complementary. ${ }^{83}$ Hermeneutics wants to identify within the work what the text is trying to say, but "this discourse is given nowhere else than in

\footnotetext{
${ }^{74}$ For an exploration of how these activities may assume forms of legal expression in various cultures, see Bernard J. Hibbitts, "Coming to Our Senses": Communication and Legal Expression in Performance Cultures, 41 EMORY L.J. 873 (1992).

${ }^{75}$ Ricoeur, Objectivation et Aliénation, supra note 68, at 34-35 (citing Dilthey).

${ }^{76} I d$. at 35 .

${ }^{77}$ Paul Ricoeur, The Model of the Text: Meaningful Action Considered as a Text, in HERMENEUTICS AND THE HUMAN SCIENCES, supra note 73, at 197, 203 (action as objectification); Paul Ricoeur, Explanation and Understanding, in THE PHILOSOPHY OF PAUL Ricoeur 149, 160 (Charles E. Reagan \& David Stewart eds., 1978) (action as exteriorization). As with discourse, action's exteriorization permits its subsequent inscription in archives and documents. Id.

Analogy can be properly drawn here to the work of anthropologist Clifford Geertz. See Clifford GeERTZ, The InTERPRETAtion of Cultures (1973). Geertz's concept of culture is semiotic. See id. at 5. The "thick description" of cultural meaning that is his aspiration, see, e.g., id. at 7, he explicitly analogizes to interpreting a literary text. See id. at 448. "[C]ultural forms can be treated as texts, as imaginative works built out of social materials . . ." Id. at 449. Geertz makes plain that he borrows the idea of the inscription of action from Ricoeur. See id. at 19. Radin also cites Geertz but not to similar effect. See, e.g., RAdin, ConTESTED Commodities, supra note 7, at 83; Radin \& Sunder, The Subject and Object of Commodification, supra note 53, at $26 \mathrm{n} .33$.

${ }^{78}$ RicOEUR, The Task of Hermeneutics, supra note 73, at 62.

${ }^{79}$ Paul Ricoeur, Ethics and Culture, in POLITICAL AND Social EsSAYs 243, 264 (David Stewart \& Joseph Bien eds., 1974).

${ }^{80}$ RAdin, CONTESTEd COMMODITIES, supra note 7, at 38.

${ }^{81}$ Ricoeur, Objectivation et Aliénation, supra note 68, at 27.

${ }^{82} I d$. at 35 .

${ }^{83}$ Ricoeur, Philosophical Hermeneutics, supra note 68, at 19; Paul Ricoeur, The Hermeneutical Task of Distanciation, in HeRmeneutics AND THE Human SCIENCES, supra note 73 , at $131,140$.
} 
and by the structure of the work." ${ }^{\prime 4}$ For our purposes, it is also provocative that Gadamer calls what the text is trying to say the "thing" of the text. ${ }^{85}$

A second level of exteriorization takes us beyond the objectification of personhood in individual outward expressions or actions to the objectification that may be operable in a larger discourse, theory, story, or doctrine. Consider Radin's many writings, for example. They are all exteriorizations and objectifications of herself and the ideas and arguments she wants to express. Ricoeur comments, "[D]iscourse displays a quite high level of objectification, similar to that of the products of work in relation to the process of production. Man objectifies himself through the works of his discourse, as he does through the products of his craftsmanship, and his art." ${ }^{" 86}$ Part of our aim here is again to draw attention, now at the level of discourse, to how exteriorization or objectification can be positive and worth preserving. We also want to go further, though, to evaluate how Radin's method, in its discussion of policy and doctrine, falls along the spectrum between the poles of metaphoric and speculative or conceptual discourse. We argue that although Radin demonstrates some sensitivity to and adherence to more conceptual discourse, she typically aligns with more metaphoric discourse. She only limitedly endorses conceptual discourse, because it is more objectifying. We will turn in Part III to contend that in intellectual property law, objectifying discourse can be more positive and less reifying than Radin allows.

The poles of metaphoric and conceptual discourse can be well represented by Carol Rose's distinction in property law between crystalline rules and muddy ones. ${ }^{87}$ Crystal rules are "hard-edged," or in our vocabulary reductive and univocal; they are imposed regardless of context. ${ }^{88}$ Muddy rules, by contrast, are attentive to context; they are more relational, more metaphoric. They are more discretionary, equitable judgments. ${ }^{89}$ In her review of various property doctrines, Rose finds a cycle that "alternates between crystals and mud." 90

Radin's analyses encompass both more metaphoric and more conceptual forms of discourse. Her theory of personhood, for example, appreciates both the need for stability and flexibility. "For appropriate self-constitution," she writes, "both strong attachment to context and strong possibilities for detachment from context are needed." ${ }^{11}$ Regard for more ideal theories of personhood-of freedom and identity - is appropriate, yet, she continues: "[A]s a pragmatist, I believe nonideal theory is also necessary, because our visions about the nature of human beings and of

\footnotetext{
${ }^{84}$ Ricoeur, Philosophical Hermeneutics, supra note 68, at 22.

${ }^{85}$ See id. at 30 (describing how Gadamer calls the "what" of the text "die Sache des Texts, the 'thing,' the 'issue at stake' in the text, the in re of the text"). No specific reference to Gadamer is provided.

${ }^{86} I d$. at 21.

${ }^{87}$ See Carol M. Rose, Crystals and Mud in Property Law, in Property and Persuasion, supra note 5, at 199.

${ }^{88}$ See id. at 199.

${ }^{89}$ See id. at 200.

${ }^{90} I d$. at 205.

${ }^{91}$ RADin, CONTESTED COMMODITIES, supra note 7, at 61.
} 
the good life for human beings cannot be too far divorced from the circumstances that give rise to those visions ...." ${ }^{92}$ The pragmatic element in Radin's analyses is the strongest, and her very attentiveness to context and circumstance places her more toward the relational, metaphoric end of discourse. This relational emphasis pervades her work. She writes of her pragmatism: "A serious pluralism . . . makes possible a commitment to dialogue among alternative conceptions." writes elsewhere, "may not be some absolute value apart from the debate; but truth may still be conceived to be the end result of unconstrained conversation." ${ }^{94}$ As we have previously discussed ${ }^{95}$ Radin's contribution in the present Symposium is full of relational language. "[W]hat counts as property is malleable."96 Various aspects of property are contested. ${ }^{97}$ Property interests must be balanced. ${ }^{98}$ Property doctrinethe "propertization neighborhood"- must itself be interrelated to other doctrinal neighborhoods so that is "aware of its function within the city as a whole."

Yet within this generally relational approach of Radin's, we want to return to the possibilities she permits of doctrinal and theoretical objectification. She and Frank Michelman write that at the same time that they reject the formalist conception of rules, their pragmatism also leads them to reject claims that "all notions of ruleness are misleading, all pretenses of ruleness misdirected." 100 It is inappropriate simply to decide on the basis of "case-by-case judgment, situated decisionmaking moment by moment." 101 This kind of "[r]adical particularism is incomplete pragmatism because it shirks the hard pragmatic work of calibrating ruleness to context." ${ }^{\prime 102}$ While it may be true that "each and every normative project is liable to deconstruction," it is also the case that "the reconstructive moment seems ineradicable."103 Writing in this Symposium, Radin endorses the need for "coherence across doctrinal, policy, and practical boundaries." 104 She wants to achieve a "satisfactory kind of analysis." 105

\footnotetext{
${ }^{92} I d$. at 63.

${ }^{93}$ Margaret Jane Radin, The Pragmatist and the Feminist, 63 S. CAL. L. REV. 1699, 1725$26(1990)$.

${ }^{94}$ RAdin, CONTESTED COMMODITIES, supra note 7, at 166.

${ }^{95}$ See supra text accompanying notes 4-11.

${ }^{96}$ Radin, Information Propertization, supra note 2, at 23.

${ }^{97}$ Id. at 24 .

${ }^{98}$ Id. at $25-27$.

${ }^{99} I d$. at 23.

${ }^{100}$ Margaret Jane Radin \& Frank Michelman, Commentary, Pragmatist and Poststructuralist Critical Legal Practice, 139 U. PA. L. REV. 1019, 1046 (1991).

${ }^{101}$ Id.

${ }^{102} I d$.

${ }^{103} I d$. at $1057-58$.

${ }^{104}$ Radin, Information Propertization, supra note 2, at 27.

${ }^{105} \mathrm{Id}$. at 38 .
} 
Elsewhere Radin supports the role that "conceptual transformations" can play. ${ }^{106}$ She appreciates that regulation discouraging commodification would underwrite "a conceptual structure." 107 She approves making "policy decisions that take into account our vision of the whole, however extraordinarily difficult that may be."108

Reconstruction, coherence, analysis, conceptual transformation, conceptual structure, and visions of the whole are all analytic and conceptual moves that objectify; they direct and constrain; they do not let metaphor run free. ${ }^{109}$ In the midst of her relational approach, Radin allows that this approach also needs analytic rigor and precision; judgment is not simply situational, simply protean. ${ }^{10}$ This interrelation of the metaphoric or relational and the conceptual or analytic is similar to what we endorsed in the earlier pages on externalization. Conceptual objectification is not a negative. It may also be ineluctable. Across the spectrum from metaphoric to speculative discourse, the reach of the conceptual or analytic is far. Ricoeur writes, for example: "[T] narrate is already to explain." is a construct; the "facts" do not present their own story. Even stable metaphors constrain and orient us in certain ways. ${ }^{112}$

If conceptual or doctrinal objectification is not the enemy, then part of the task is to ascertain in differing contexts how various sorts of objectification - from narrative to rule - can serve various conceptual, policy, and legal goals. ${ }^{113}$ Part of the task also

\footnotetext{
${ }^{106}$ Radin, Objectification, supra note 64 , at 341.

${ }^{107}$ RADin, CONTESTED COMMODITIES, supra note 7, at 176; see also id. at 173 (noting how "it seems that the state is always involved in preferring one discourse to another").

${ }^{108}$ Radin, Objectification, supra note 64 , at 344 . Likewise, she maintains that a vision of the whole will change as particular policy decisions are made. See id. This interplay of whole and part is analogous to the hermeneutic interrelation of meaning and application, discussed earlier. See supra text accompanying notes 14-15.

${ }^{109}$ Cf. Ricoeur, The Rule of Metaphor, supra note 16, at 261 ("Philosophical discourse sets itself up as the vigilant watchman overseeing the ordered extensions of meaning; against this background, the unfettered extensions of meaning in poetic discourse spring free.”).

${ }^{110}$ Think analogously of how Ertman \& Williams situate their edited collection of new scholarship on commodification: "In the belief that the right tool is half the job, we hope that this book will help crystallize a new approach to commodification." Ertman \& Williams, Preface, supra note 61, at 5. A tool is analytic. Note also the reference to crystallization, which likely unintentionally recalls Rose's use of the term. See supra text accompanying note 88 .

${ }^{111} 1$ Paul Ricoeur, Time and Narrative 178 (Kathleen McLaughlin \& David Pellauer trans., 1984).

${ }^{112}$ Recent work in cognitive theory argues that the structured conceptual systems in the mind such as metaphor not only "make it possible for us to experience things the way we do," LAKOFF \& JOHNSON, supra note 16 , at 509, but their commonality and stability help account for how stable knowledge is possible. Id. at 96. For elaboration of the differences between the theories of metaphor of Ricoeur and of Lakoff and Johnson, see George H. Taylor, Cognitive Theory, Conscience, and Law, 6 GRAVEN IMAGES (forthcoming 2006).
}

${ }^{113}$ The work of Carol Rose, for example, analyzes why property discussions resort to narrative rather than exclusively more scientific analytic approaches. See Rose, supra note 5, at 27 . 
is to differentiate conceptual and doctrinal objectification from conceptual and doctrinal reification. In Part III, we turn to examples from intellectual property to discuss and elaborate more concretely this distinction, but let us close this Part and introduce the next by way of an example of Radin's that illustrates the issue. In a recent article on Information Tangibility, ${ }^{114}$ Radin expresses concern that "[a]ssimilation of information to the category of tangibility is fostering commodification; that is, a great increase in the scope of intellectual property and allied regimes of privatized information control." 115 According to Radin, the traditional understanding of intellectual property is that it is composed of something internal to a person that becomes propertizable when embodied in an external, tangible object. ${ }^{116}$ Commodification was "linked to embodiment in a physical object." 117 Whatever our cautions about Radin's portrayal of this understanding, ${ }^{118}$ which she relates back to Kant and Hegel, ${ }^{119}$ we attend here Radin's claim that this traditional understanding no longer operates in the digital world. There has been a movement to delete recognition of digital information as a product of personhood and to "redescribe the information itself as a physical object from the outset." 120 Many courts and commentators have accepted that a computer memory's arrangement of electrons is not intangible information but a tangible physical object, and this has led to many online activities being copyrighted that were not similarly protected offline. ${ }^{121}$ For Radin, as we have come to expect, her larger objection is that the more information can be assimilated to objects, the more it is susceptible to commodification. $^{122}$ We again wonder, though, whether objectification is the primary issue or whether instead reification is. Digital information has lost its relation to its origin as human expression, human externalization. Although her resulting analysis differs from ours, she captures the problem neatly: "The metaphor of physicality, of object-ness, has become ever more rhetorically literal." ${ }^{\prime 23}$ The reduction of the phenomenon to the literal reifies the phenomenon, cuts it off from its roots. More generally, the issue should not be that something is propertizable because of its objectification as a thing or object but is propertized because of normative judgments about how to conceptualize the thing or object. ${ }^{124}$ There may be rhetorical power in assimilating something to the physical, but the rhetorical

\footnotetext{
${ }^{114}$ See Radin, Information Tangibility, supra note 11.

${ }^{115} I d$. at 397. This concern is also apparent in her article in the present volume. See Radin, Information Propertization, supra note 2.

${ }^{116}$ Radin, Information Tangibility, supra note 11, at 398.

${ }^{117}$ Id. at 406.

${ }^{118}$ See supra text accompanying notes $34-41$.

${ }^{119}$ See Radin, Information Tangibility, supra note 11, at 397-98.

${ }^{120}$ Id. at 417 .

${ }^{121}$ Id. at 406.

${ }^{122} I d$. at 417 .

${ }^{123}$ Id. at 402 .

${ }^{124}$ See supra text accompanying notes 7-8 (discussing the interrelation of fact and value).
} 
nature of the claim should be the point of examination. ${ }^{125}$ As we now turn to pursue through examples drawn from intellectual property law, the issue is not whether something is externalized and objectified but whether that objectification turns into reification. ${ }^{126}$

\section{TOWARD AN ACCOUNT OF OBJECTIFICATION AND BOUNDARIES}

In this Part, we want to relate this understanding of Radin's work on commodification, enhanced via application of Ricoeur's perspective, briefly to more recent work on commodification and to Radin's recent work on property theory and technology. More generally, we note that the problem that commodification theory describes, the problem of things, and signs, and interpretation, describes a problem of salience and permeability. What we describe is, as it is for Radin, essentially a problem of boundaries, that is, the problem of distinguishing between those "things" that we value and want to promote, and those "things" that we abhor.

Within commodification theory itself, scholars have come to recognize the virtues of things. Carol Rose, in her afterword to the recent volume Rethinking Commodification: Cases And Readings In Law And Culture, ${ }^{127}$ writes:

Things are both commodities and not commodities. Markets seem inappropriate for some things, but then again, maybe markets are pretty useful for exactly the same things. It is interesting that several of the essays in this volume return to some of Appadurai's ideas about "commoditization" (awkward language and all), and particularly to the idea that over time, things slip in and out of the status of commodity. But when? And when not? This is the set of questions that the new commodification theory seems to be addressing. ${ }^{128}$

\footnotetext{
${ }^{125}$ See Rose, supra note 5, at 297:
}

With property, the nature of "things" imposes their own quite fascinating constraints. Yet even with those, what you see in property is what you and others have talked yourselves into about those "things"; and given some imagination, you may always talk yourselves into seeing something else - with all the effects on understanding and action that a new "envisioning" may bring.

${ }^{126}$ For brief consideration of the further fruitfulness of an analysis of the interrelations between metaphor, objectification, and reification, consider its implications for an analysis of the sociology of organizations. It is a considerable question, for instance, how institutions can maintain their originative ethos or vision over time rather than become focused simply on selfperpetuation. David Kennedy has recently examined this problem in the context of international human rights organizations. See DAVID KenNEDY, The DARK Sides OF VIRTUE (2004). The classical treatment of this issue can be found in Max Weber's discussion of the bureaucratic routinization of charisma. See 2 MAX WeBER, ECONOMY AND SocIETY 1121-23 (Guenther Roth \& Claus Wittich eds., 1978). In our vocabulary, the question here can be expressed as how the institution's originative metaphoric impulse can be objectified rather than reified. Arthur Mitzman types Weber's work precisely a "sociology of reification." Arthur Mitzman, The Iron Cage: An Historical Interpretation of MAX Weber 176 (1969).

${ }^{127}$ Rose, Afterword, supra note 53.

${ }^{128} I d$. at 404 . 
Radin's co-authored contribution to that book likewise acknowledges the complexity of modern problems of commodification and the virtues of markets, ${ }^{129}$ recognizing the semiotic significance of things, and how that significance not only charges markets with the conditions of victimhood, but may offer tools for escape. In that piece Radin is skeptical of the normativity of things, even while commodification may be strategically useful. But her paper for this symposium seems to be more sympathetic to the normative argument. The question is in part, as she argues, who controls the meaning of the thing. When Radin recognizes that the problem of property does not have a single valence that might be described as "commodification [and markets] bad" and calls for situating propertization problems in a community of zones that includes competition and free speech "neighborhoods," the point is not merely descriptive.

We propose, however, a broader form of the question, and a form that is, perhaps, less susceptible of response along a single dimension. The question is not only who controls the meaning of the thing, but how that meaning is created. The "neighborhood" metaphor evokes a broader discussion about the character of neighborhoods, both real and metaphorical. How do we identify a "neighborhood," and how do we ordinarily understand its various relationships-with other neighborhoods, with its inhabitants, with the city or broader community of which it is a part? Our inner "urban planner" has much to say on all of these questions, but we want to preface this by grounding the discussion in terms of a distinction drawn by Isaiah Berlin. Berlin described two fundamentally different roles, or identities, though which individuals understand the world. On the one hand, there are the systematizers, for whom knowledge proceeds from what might be called "universalizing rationalism," grand, orderly systems that organize human endeavor based on rules and their application. ${ }^{130}$ On the other hand, there are the humanists, for whom knowledge proceeds not from rigorous application of method, but from understanding. The stuff of our lived experience - empathy, rhetoric, and practiceis also the stuff of knowledge. Working out the relationship between the relational and objectification, and describing and applying an appropriate set of tools for doing so, requires some careful accommodation of both perspectives. It isn't the case that there is a single, overarching, and preferred method for balancing the two arguments for property that Radin describes in her contribution to this symposium, the Demand Side/Column A and the Supply Side/Column B. ${ }^{131}$ Nor is it the case that any question of balancing involves an unbounded inquiry into public policies, where the parties fight over the "right" set of policies to consider and the "right" level of abstraction to use in the debate. Rather, we describe a series of interconnected themes that we draw from the stuff of law itself, themes that law and policy can use

\footnotetext{
${ }^{129}$ Radin \& Sunder, The Subject and Object of Commodification, supra note 53.

${ }^{130}$ See Isaiah Berlin, The Divorce Between the Sciences and the Humanities, in Against THE CURRENT: ESSAYS IN THE History OF IdEAs 80 (1979); ISAIAH BERLIN, Vico's Concept of Knowledge, in AgAinst the CURRENT: EsSAys In THE History OF IDEAs 111 (1979); IsAiAH BERLin, Vico and the Ideal of the Enlightenment, in AgAINST THE CURRENT: ESSAYS IN THE History OF IDEAS 120 (1979); IsAiAH BERlin, The Concept of Scientific History, in CONCEPTS AND CATEgories: Philosophical Essays 103 (Henry Hardy ed., 1979); IsAiah Berlin, Vico AND HERdER: Two STUdies IN THE History OF IdEAS (1976).

${ }^{131}$ Radin, Information Propertization, supra note 2, at 25-27.
} 
and has used in a number of contexts to process problems of objectification and interpretation, that is, control of meaning and the boundary problem at the core of commodification theory.

In brief, those themes are: (i) metaphor, language and symbol, rooted in the related disciplines of cognitive psychology, on the one hand, and the hermeneutic principles of interpretation described in the last Part, on the other; (ii) narrative and storytelling, which also embraces some aspects of ritual and community, i.e., propertization's social milieu, in addition to its legal and economic milieu; (iii) the domain of objects, that is, the thingness of things constructed by and for the law; (iv) space and place, which we understand as including both the metaphorically and literally physical or spatial character of social and legal relations; and (v) discipline and social practice, or, in other words, forms of collective understanding and behavior. None of these is truly independent of the others. All of them are rooted, at one level or another, in concerns of metaphor and concept as well as in experience and pragmatics. They are each systematic in a sense, yet simultaneously based in and constructed from the everyday. At the same time, none of them, or even all of them taken together, is a complete answer to the problem posed by the distinction between commodification and objectification. We offer them tentatively, as possibilities for further exploration and research.

\section{A. On Metaphor and Language $e^{132}$}

The first and perhaps most important source of differentiation is language itself. "Commodification" and "commoditization," "thing-ness" and "thingy-ness" and "thingification" are difficult terms, but they capture something imperative about our experience of the world. ${ }^{133}$ We argue that language is essentially metaphorical, ${ }^{134}$ and that metaphors are not merely literary, but cognitive. ${ }^{135}$ Language maps deep cognitive structures and thus mirrors cultural patterns and social structures. ${ }^{136} \mathrm{We}$

\footnotetext{
${ }^{132}$ Some of this material was presented previously in Michael J. Madison, A PatternOriented Approach to Fair Use, 45 WM. \& MARY L. REV. 1525 (2004).

${ }^{133}$ See, e.g., Michael A. Heller, The Boundaries of Private Property, 108 YALE L.J. 1163 (1999); Thomas W. Merrill \& Henry E. Smith, What Happened to Property in Law and Economics?, 111 YALE L.J. 357, 359, 384-85 (2001).

${ }^{134}$ See, e.g., GeOrge Lakoff, Women, Fire, and Dangerous Things: What CATEgories Reveal About the Mind (1987); George Lakoff \& Mark Johnson, Metaphors We Live By (1980); George Lakoff \& Mark Turner, More Than Cool Reason: A Field Guide to POETIC METAPHOR (1989).

${ }^{135}$ See Mark Turner, Cognitive Dimensions of Social Science 144-45, 159-62 (2001) (describing the functions of conceptual schema in thought and action); Paul DiMaggio, Culture and Cognition, 23 ANN. REV. Soc. 263, 269-74 (1997) (describing a tentative synthesis of cognitive arguments in sociology that conclude that behavior results from interaction between external rituals and internal mental structures).

${ }^{136}$ See Dan Hunter, Reason Is Too Large: Analogy and Precedent in Law, 50 EMORY L.J. 1197, 1208-10 (2001). On the role of metaphor in shaping the law, see generally ANTHONY G. AmSTERdAM \& Jerome Bruner, Minding THE LAW 189-92 (2000) (describing the Supreme Court's repetitive use of a new word in different contexts until its meaning is shaped). The influence of classification on institutional behavior can't be ignored; creation, interpretation, and application of metaphor is an iterative process. See generally ISAIAH BERLIN, CONCEPTS
} 
talk as we do because of how we think and act, rather than the reverse. ${ }^{137}$ Linguistically, our categories are built largely on our experiences.

George Lakoff proposes that metaphoric meanings are mapped to experience on a one-to-one target (metaphor) to source (experience) basis. Gilles Fauconnier and Mark Turner elaborate this thesis, arguing that we experience overlapping metaphorical frameworks. ${ }^{138}$ Each of these frameworks comprises a "mental space" constructed by a listener or reader and consisting of elements, roles, strategies, and relationships, all of which the listener uses in reasoning and creating meaning. Overlapping "mental spaces" are linked via the process of "cognitive blending," which accommodates dynamism in the process of understanding. ${ }^{139}$ Querying the extent and stability of a linguistic practice is a way of decoding the extent and stability of the corresponding behavior and social practice. Moreover, that investigation inevitably has both descriptive and normative dimensions. ${ }^{140}$ Our use of metaphor carries with it an evaluative dimension that is always at least implicit. In large part, to bring metaphor and language into the foreground of the boundary distinguishing commodity from object is to make that evaluation explicit.

Armed with this perspective, we can see the work of language and metaphor in legal analysis all around us. Radin's contribution frames her discussion in terms of neighborhoods and cities, a metaphorical mapping of legal doctrine onto physical territory. The neighborhood metaphor is not the only one at hand, however, even if physical metaphors are deeply embedded in our thinking about property. Managers in businesses deal with disciplinary single-mindedness, but they often refer to the problem as one of "silos" rather than as one of "neighborhoods." Edward Rubin has explored the role of metaphor in law in a number of different contexts. In corporate law, he observes that our metaphoric "image" of the corporation affects our presumptions about the character of corporate regulation. ${ }^{141}$ In administrative law,

ANd Categories: Philosophical Essays (Henry Hardy ed., 1979); Geoffrey Bowker \& Susan Leigh StaR, Sorting Things OUt: ClassificATION AND ITS CONSEQUENCES (1999).

${ }^{137}$ LAKOFF, supra note 134 , at 135.

${ }^{138}$ See Mark Turner \& Gilles Fauconnier, Laughing At and Laughing With: The Linguistics of Humor and Humor in Literature, in THE WORKINGS OF LANGUAGE: From PrESCRIPTIONS to PersPeCtives 181, 186-99 (Rebecca S. Wheeler ed., 1999).

${ }^{139}$ See Gilles Fauconnier, Mental Spaces: Aspects of Meaning Construction in Natural Language 16-22 (1985); Gilles Fauconnier, Mappings in Thought AND LANGUAGE 21-23, 149-92 (1997); Turner \& Fauconnier, supra note 138, at 186-89.

${ }^{140}$ See id. at 65 ("We not only import entities and structure from the source domain to the target domain, we also carry over the way we evaluate the entities in the source domain."); Pierre Schlag, The Aesthetics of American Law, 115 HARV. L. REV. 1047, 1050 (2002) (arguing that "the aesthetic pertains to the forms, images, tropes, perceptions, and sensibilities that help shape the creation, apprehension, and even identity of human endeavors, including, most topically, law"); Steven L. Winter, Transcendental Nonsense, Metaphoric Reasoning, and the Cognitive Stakes for Law, 137 U. PA. L. REV. 1105, 1143-46 (1989).

${ }^{141}$ Edward L. Rubin, Images of Organizations and Consequences of Regulation, 6 THEORETICAL INQUIRIES L. 347, 363 (2005). 
Rubin argues the traditional hierarchical metaphor of governance should be replaced by the more descriptively accurate "network" model. ${ }^{142}$

The metaphoric approach is equally significant when we move from broad regulatory metaphors to more precise applications of metaphor to legal doctrine. Radin repeats the common criticism of the use of physicalist metaphors in legislation and judicial decisions applying intellectual property rules to the internet, in the context of the Digital Millennium Copyright Act, for example, and the curious contemporary application of the doctrine of trespass to chattels. ${ }^{143}$ It is important to recognize, however, that the metaphor does not necessarily stand in the way here. Because of its centrality to our ordinary experience, metaphor can be an important tool for progressive analysis. In intellectual property law, James Boyle has championed a call for "cultural environmentalism" on the Internet, ${ }^{144}$ a theme that manifests itself in concrete proposals to preserve (and conserve) a "commons," which is metaphorically related to but distinct from the public domain. Boyle's "environmentalism" is in the first place a product, not a driver, of a shared sense that intellectual property issues pose problems of inter-generational resource allocation and stewardship, for example. To speak of an object as a thing or as a commodity, is not necessarily to construct a category for political and legal rhetoric. It may be to introduce our actual experience into the policy debate.

The problem of the "commons" in intellectual property law is precisely the sort of problem that discerning the boundary between "good" and "bad" objectification is designed to investigate. The most recent example of the metaphoric approach to this relationship, in the context of the commons, is the inquiry by the United States Copyright Office into the problem of what are now universally referred to as "orphan" works. ${ }^{145}$ "Orphan" works are copyrighted works whose owners can no longer be found. The familial metaphor is not original to this inquiry; there is a long custom in intellectual property law and among authors themselves of both believing that books and other expressive works are the "children" of their creators and referring to those works accordingly. ${ }^{146}$ Creators, like parents, have the presumptive right to control the experience of their "children" in the world and to shield them from exploitation and abuse, and advocates for strong authorial rights implicitly and sometimes explicitly invoke that emotional bond to justify a legislative or judicial result. ${ }^{147}$ On the other hand, the metaphor is regarded as offering a poor fit for American copyright law, since it is often invoked in support of forms of "moral

\footnotetext{
${ }^{142}$ Edward L. Rubin, Beyond Camelot: Rethinking Politics and Law for the MODERN STATE (2005).

${ }^{143}$ Radin, Information Propertization, supra note 2, at 34-36.

${ }^{144}$ James Boyle, The Second Enclosure Movement and the Construction of the Public Domain, 66 LAW \& Contemp. Probs. 33 (Winter/Spring 2003); James Boyle, A Politics of Intellectual Property: Environmentalism for the Net?, 47 DUKE L.J. 87 (1997).

${ }^{145}$ U.S. COPYRIGHT OFFICE, REPORT ON ORPHAN WORKS (2006), available at http://www. copyright.gov/orphan/.

${ }^{146}$ The cartoonist Gary Larson invoked the metaphor in a famous attempt to retrieve copies of "The Far Side" cartoons from early websites. The episode is described in William W. Fisher III, Property and Contract on the Internet, 73 CHI-KENT L. REV. 1203, 1221-22 (1998).

${ }^{147}$ N.Y. Times Co., Inc. v. Tasini, 533 U.S. 483 (2001).
} 
rights" - rights of attribution of the work, and of integrity of the work - that are only weakly represented in American law.

The recent Copyright Office report, however, uses that metaphor in a more progressive sense. Having recognized the metaphor, the office explicitly adopts its normative implications: If copyrighted works implicitly have "parents," rather than authors and publishers, the "orphan" label is consistent with viewing the orphan works problem much as child welfare advocates view the problem of abandoned and abused children. The policy problem here is that new users of those works may propose valuable uses but be discouraged from pursuing them, out of fear that publicity accompanying the use will lead the disappeared owners to emerge and demand supra-market compensation, and even injunctive relief. The Office produced a report that explicitly recognized the problem in "orphan" terms and that proposed a concrete remedy: a legislative fix that would limit remedies available to newly-appearing owners of truly "orphan" works. The proposal may or may not suit all claims equally, but it is clear that the metaphor offers a useful frame for analyzing the issue.

\section{B. On Stories ${ }^{148}$}

It is important to begin with language and metaphor, but not to end with it. Experience may produce language, but our use of metaphor is interpretive and iterative, even if individual words and phrases evoke meaning that expresses our experience in a direct way. Equally important, describing the problem of boundaries as a problem of language obscures not only the identity of the persons or groups whose experiences matter, but also the mechanism by which those experiences get inscribed linguistically. Supplementing the linguistic perspective with others becomes critical.

Most of us create meanings for our lives by blending experience and metaphor into stories. Narrative, then, supplies a second tool for approaching the distinction between commodity and object. We focus on narrative in two distinct, but related, senses. First, there is the modern academic sense of "narrative" as a social construct that integrates diverse phenomena into some meaningful, if necessarily incomplete, whole. ${ }^{149}$ This is partly Robert Cover's nomos, ${ }^{150}$ and it is also importantly what Martha Nussbaum commended as an act of "literary imagination."151 In law,

\footnotetext{
${ }^{148}$ The material in this Section is drawn in part from Michael J. Madison, The Narratives of Cyberspace Law (or, Learning from Casablanca), 27 COLUM. J.L. \& ARTS 249 (2004).

${ }^{149}$ The relationships among law, literature and narrative form a rich field of scholarly inquiry. Scholars urging critical examination of jurisprudence from literary, aesthetic and/or narrative perspectives include: Martha C. Nussbaum, Poetic Justice: The Literary Imagination And Public Life (1995); Richard Weisberg, Poethics AND Other Strategies of LaW and Literature (1992); Robin West, Narrative, Authority, and LAW (1993); Robert M. Cover, The Supreme Court, 1982 Term - Foreword: Nomos and Narrative, 97 HARV. L. REV. 4 (1983). The role of literary perspectives in constructing a normative vision of law and legal practice is explored in the work of James Boyd White. See, e.g., James Boyd White, Acts of Hope: Creating Authority in Literature, LaW, AND POLITICS (1994).

${ }^{150}$ See Cover, supra note 149 , at 4-5.

${ }^{151}$ See NussBAUM, supra note 149 , at 3-12.
} 
narrative permits us to both see the world as it is, by structuring apparently disparate phenomena, and perhaps to understand or imagine, as a writer might do, the world as it might be. ${ }^{152}$

There is also, of course, the related and powerful sense of "narrative" as story, as a tale that has power and relevance because it has a beginning, a middle and an end. In this context, metaphor is this Aristotelian narrative, ${ }^{153}$ rather than Platonic essence. We ask, for example, what is the story of the copyrighted work whose author cannot be located, rather than "is this an orphan work"? Theoretical constructs, metaphors and technologies, that is, commodities and objects, become characters, settings, themes and plots. ${ }^{154}$

Where do we find these narratives, or how do we construct them? Narrative requires the same tools that metaphor supplies: our lived experience, with character, and movement, and boundaries. Even the online world, with its apparent boundlessness,${ }^{155}$ supplies these things in a growing variety of ways, linear and traditional as well as non-linear and unconventional. Cyberspace is determined and bounded by the processes by which it is created and experienced. The boundaries of cyberspace are recursive, generated dynamically both via human engagement and via technological processes, and constantly re-determined. Boundaries do exist, if in a non-traditional sense, at the levels of software and communications protocols that enable digital communication and at the level of computer software that we engage as users. ${ }^{156}$ We can, as a result, tell both traditional and non-traditional stories about law. ${ }^{157}$ Stories are determined recursively by the processes of their telling and retelling. The reader is merely establishing one pattern from among a large number of patterns whose potential is embedded in the technology. Traditional text-based narratives are historically contingent instantiations of a cognitive framework for the recognition of meaning in context. The narrative construct does not depend on a

${ }^{152}$ Aristotle: PoEtics 516, at 59 (Stephen Halliwell ed. \& trans., 1995):

[I]t is not the poet's function to relate actual events, but the kinds of things that might occur and are possible in terms of probability or necessity. The difference between the historian and the poet is not that between using verse or prose; Herodotus' work could be versified and would be just as much a kind of history in verse as in prose. No, the difference is this: that the one relates actual events, the other the kinds of things that might occur.

${ }^{153} C f$. Paul Ricoeur, 1 Time and Narrative 31- 51 (Kathleen McLaughlin \& David Pellauer trans., 1984) (providing an account of the centrality of narrative in Aristotelian thought to rhetoric and ethics, as well as poetics).

${ }^{154}$ See Michael J. Madison, Where Does Creativity Come From? and Other Stories of Copyright, 53 CASE W. RES. L. REV. 747 (2003).

${ }^{155} \mathrm{See}$, e.g., Janet H. Murray, Hamlet on the Holodeck: The Future of Narrative IN CYBERSPACE 65-94, 173-75 (1997). For legal theorists, the significance of the boundaryless Internet is most forcefully argued in David R. Johnson \& David Post, Law And Borders-The Rise of Law in Cyberspace, 48 STAN. L. REV. 1367 (1996).

${ }^{156}$ See LAWrence Lessig, COdE AND OTHER LAWS OF CyBERSPACE (1999).

157 See Shulamit Almog, From Sterne and Borges to Lost Storytellers: Cyberspace, Narrative, and Law, 13 Fordham InTELl. Prop. MEdiA \& ENT. L.J. 1 (2002). 
particular technology. ${ }^{158}$ There are many beginnings and many ends, rather than one of each. The reader or user chooses and, in doing so, selects the boundaries of his or her own experience.

What this describes from a socio-technical perspective obviously stands in metaphorically for what happens in law. ${ }^{159}$ We can differentiate commodities from objects, bad things from good things, in part by explicitly explaining, exploring, and contrasting the narratives that can be constructed out of them. We cannot do this comprehensively before the fact, that is, as a way of categorizing something ex ante as one form or another. Instead, we rely on narrative after the fact to validate the synthesis that we think is both pragmatically and morally correct.

Carol Rose shows that narrative methodology can be applied in property law contexts at almost any level of abstraction, and that it can be used predictively and instrumentally as well as symbolically. ${ }^{160}$ In intellectual property law, a particularly clear example comes from the recent debate over the lawfulness of "file sharing" or "peer-to-peer" (P2P) technologies for distributing computer files on the internet. Today, that debate is framed by a case decided more than 20 years ago, involving the lawfulness of the videocassette recorder. In Sony Corp. of America v. Universal City Studios ${ }^{161}$ the Supreme Court upheld distribution of the VCR over the challenge that the machine enabled widespread copyright infringement by home users making unauthorized recordings of broadcast television programs. Those home users, a majority of the Court concluded, were engaged in lawful "time-shifting" of television shows by recording them for later viewing. As subsequent commentators have often pointed out, however, not only was the evidence of "time-shifting" by VCR users far more equivocal than the Court acknowledged, but Sony, the manufacturer and defendant in the case, had marketed the machines for use in taping and archiving favorite television programs. One might conclude, with only a bit of rhetorical excess, that the story of the case proved to be more persuasive than the facts.

Today, the Sony precedent is the starting point for evaluation of $\mathrm{P} 2 \mathrm{P}$ file sharing networks, such as Napster, Aimster, and Grokster. Defenders of those networks

\footnotetext{
${ }^{158}$ JOSEPH TABBI, COGNITIVE Fictions xi (2002) ("A similar interdependence [between the individual and the environment], through which a bounded and stable structure is continually produced, might better describe what is actually going on within today's changing media environment."); see also George H. Taylor, Critical Hermeneutics: The Intertwining of Explanation and Understanding as Exemplified in Legal Analysis, 76 CHI.-KENT L. REV. 1101,1123 (2000):

The model for law need not necessarily derive from the deterministic, nomological form of explanation commonly identified in the physical sciences but may find more appropriate analogue in the interrelation of regularity and exception found in biology. A sophisticated narrative approach--informed by both interpretive understanding and explanation--can be an appropriate, indeed arguably is the most appropriate, methodology in law.

${ }^{159}$ See, e.g., Paul Schiff Berman, The Globalization of Jurisdiction, 151 U. PA. L. REV. $311,321-22$ (2002) (attempting to rethink jurisdictional questions in terms of dynamic community affiliations enabled by the Internet).

${ }^{160}$ Rose, Property as Storytelling, supra note 5.

${ }^{161} 464$ U.S. 417 (1984).
} 
have suffered in copyright litigation at least in large part because they have yet to develop a narrative as persuasive as the story that "time-shifting" told. ${ }^{162}$ Timeshifting for television programming has been neologized to "space-shifting" of other entertainment media, the idea being that a consumer who pays once for a permanent copy of a song or a motion picture should be entitled to listen to or watch that content on any available, compatible device. The "shifting" here is obviously metaphorical. So far, the courts (with one small exception) have not recognized the legitimacy of the attempted narratival transfer. ${ }^{163}$ Right now, the story of free P2P networks can be reduced to a single, alternative story: theft.

The important lesson to be reaffirmed here is that metaphor and narrative do not simply happen. They are parts and products of our own lives. Advocates rely on narratives to help their clients; policymakers rely on narratives to advance agendas. The variety of our experience and the flexibility of technology suggest that we can design our own narratives. ${ }^{164}$ Articulation and distinction, and boundaries and permeability, in Radin's sense of neighborhood, often lie within our own control. ${ }^{165}$

\section{On Objects ${ }^{166}$}

The insidiousness of accepting objects uncritically lies in accepting how things mask legal and power relations within groups, between groups and individuals, and between individuals. This is the evil of reification, and in the world of digital networks and biotechnology, there is a considerable risk that conceptual reification of the legal thing (or what Margaret Radin referred to as "conceptual severance"167)

\footnotetext{
${ }^{162}$ See Metro-Goldwyn-Mayer Studios Inc. v. Grokster, Ltd., 125 S. Ct. 2764 (2005) (presuming that consumer use of $\mathrm{P} 2 \mathrm{P}$ system is infringing); In re Aimster Copyright Litig., 334 F.3d 643, 652-53 (7th Cir. 2003) (noting the absence of genuine evidence of any legitimate use for file sharing system), cert. denied sub nom. Deep v. Recording Indus. Ass'n of Am., 540 U.S. 1107 (2004); A \& M Records, Inc. v. Napster, Inc., 239 F.3d 1004, 1015 (9th Cir. 2001) (concluding, for fair use purposes, that end-use of file sharing services constitutes commercial use).

${ }^{163}$ The exception being dicta in Recording Indus. Ass'n of Am. v. Diamond Multimedia Sys., Inc., 180 F.3d 1072 (9th Cir. 1999) (noting that use of digital player for mp3 files to "space shift" lawfully acquired music was consistent with Congressional intent underlying "personal use" provision in Section 1008 of the Copyright Act). That case, however, is on its way to being limited to its facts, to its technology, and to its narrow context in the Audio Home Recording Act of 2002.

${ }^{164}$ See Jonathan Zittrain, The Generative Internet, HARV. L. REV. (forthcoming 2006) (on file with author) (characterizing an important benefit of the Internet as allowing people to collaborate on the creation of meaning).

${ }^{165}$ Susan Crawford argues: "[W]e are more likely to get . . . [an] optimal system if we allow communities and groups of all kinds to [define their own boundaries]," because that is likely "to permit the most valuable and interesting society to emerge." Susan P. Crawford, Shortness of Vision: Regulatory Ambition in the Digital Age, 74 FordHAM L. ReV. 695, 74344 (2005).

${ }^{166}$ Some material in this Section is drawn in part from Madison, Law as Design, supra note 1 .

${ }^{167}$ Margaret Jane Radin, The Liberal Conception of Property: Cross Currents in the Jurisprudence of Takings, 88 COLUM. L. REV. 1667, 1676-79 (1988).
} 
will be replicated in physical and digital objects themselves. A DVD that can be played only on a DVD player encoded with complementary technology obtained from an "authorized" source exercises a form of governance over human behavior that we might historically have presumed could arise only via human agency.

Yet precisely because things exercise authority, objects - especially configurable and re-configurable objects of the sort that digital and biotechnology advances now enable - can be tremendously inexpensive and effective way of communicating in those same contexts. ${ }^{168}$ Objects have semiotic or symbolic as well as instrumental virtues. Social groups, for example, both create and depend on objects. As Wendy Gordon has noted, "Shareable goods are a traditional source of binding groups together: not only standard 'public goods' such as highways and defense, but also folk tales, art, songs, and symphonies." ${ }^{\prime 69}$ Objects need not be tangible; they can be virtual. Beth Noveck observes that in social contexts on the Internet, online groups depend on stable digital representations of group members and group-related objects. ${ }^{170}$ Thomas Schelling described the concept of "focal points," now sometimes referred to as "Schelling Points," to describe objects or sites around which individuals coordinate their activities. ${ }^{171}$ Science, Technology, and Society (STS) scholars refer to "affordances" of objects in the physical world to denote the role that objects play in shaping how individuals behave and how group dynamics evolve. ${ }^{172}$ Customs, traditions, patterns, and practices of reproduction, modification, and use develop and intersect via connections to things. ${ }^{173}$ Communications channels develop to discuss, respond to, and simply to use things. Things embody information that communities and groups develop, deposit, and extract. ${ }^{174}$

Things occupy these social and authoritative roles via their presence and relative permanence, but things are not simply given. They are created, and they evolve. We tend to understand intuitively that the world around us has a constructed character, and we can use ordinary tools of regulation, much of the time, to affect its shape. For safety reasons, the federal government requires that the automobile include seat belts and air bags, for example, and a third brake light (the "Liddy light"). Digital

\footnotetext{
${ }^{168}$ Madison, Law as Design, supra note 1.

${ }^{169}$ Wendy J. Gordon, Intellectual Property, in OXFORD HANDBOOK OF LEGAL STUDIES 617, 644 (Peter Cane \& Mark Tushnet eds., 2003).

${ }^{170}$ See Beth Simone Noveck, A Democracy of Groups, 10 FIRST Monday (Nov. 2005), http://www.firstmonday.org/issues/issue10_11/noveck/index.html.

${ }^{171}$ See generally Thomas C. Schelling, The Strategy of Conflict (1960). Schelling Points are defined by reference to problem-solving and game theory, not space in particular. But they help to illuminate the problem of coordination without communication. In spatial problems, a Schelling Point is an informal location where people are likely to meet each other. They play roles similar to landmarks in navigation.

${ }^{172}$ See Donald A. Norman, Things That Make Us Smart: Defending Human AtTributes in the Age OF THE MAChine 243 (1993).

${ }^{173}$ See Aafke Komter, Heirlooms, Nikes and Bribes: Towards a Sociology of Things, 35 SOCIOLOGY 59 (2001).

${ }^{174}$ See Hanoch Dagan \& Michael A. Heller, The Liberal Commons, 110 YALE L.J. 549, 609-11 (2001) (recommending property forms that create incentives for the sorts of cooperation that occur within strong communities).
} 
technology now shows us the limits of this approach. As Radin has argued, what we ordinarily think of as legal questions can get submerged in the design of digital objects and computer programs, which deprives legal institutions of their usual regulatory levers and leaves us seemingly at a loss for what to do. ${ }^{175}$

Yet law is not really so helpless. It has quite an elaborate set of mechanisms that it uses to create and manage "thing-ness," that is, both to regulate the extent to which "legal" and "technical" issues merge, and more broadly to police boundaries between commodities and objects, that is, to recognize the good in things. Much as we suggested in the last Section that narratives of objects be made more explicit, we argue that an equivalent concern for salience can be brought to bear on things themselves. Sometimes the law reinforces thing-ness, for example, by increasing the hard edges of copyrights and patents, or software licenses, such as the open source "General Public License" that coordinates group activity. Sometimes the law disables or moderates thing-ness, by loosening those edges with exceptions and limitations. The STS tradition, which is especially attentive to changes in things over time, commends situating thing-ness by referring to practices. A thing might be defined by how it is used, an approach that we see in commercial law, for example. The law also manages thing-ness by referring to economics ("the welfare effects of things"), to bargains and contracting (via clickwrap agreements, the parties agree on what a "thing" "is," and courts get to choose whether or not to validate that agreement), to design ("it's just the way things are," or more precisely, the way the designer chooses to make the thing), and/or to the essential properties of the object ("the natural or essential character of things"). Each of these approaches has strengths and weaknesses, and no single approach is right for all occasions. But the law generally has a robust set of tools to manage this question.

As but one example, consider books. Copyright commentators have noted that the Internet lacks the material characteristics that defined traditional copyright law. In particular, the lack of "book-ish"-ness of information created, stored and distributed on electronic networks has been a cause for concern on the ground that it appears to signify the passing of an effective doctrine of first sale, ${ }^{176}$ among other things. Publishers "license" the distribution of digital books. Since consumers do not acquire ownership of their "copies," courts may decide that the doctrine of first sale does not apply; in other words, while the purchaser of a traditional book may resell that copy, the "purchaser," or rather, "licensee," of an electronic book may not do so. Part of the problem is that the question "What is a book?" has to be re-asked when text is presented in electronic form. Should it matter how books are produced? Should it matter how books are consumed? So far, it appears, what matters most is an "objective" definition of the book, and an electronic book is not "a book,"177 though the question is hardly free from doubt.

\footnotetext{
${ }^{175}$ Margaret Jane Radin, Humans, Computers, and Binding Commitment, 75 IND. L.J. 1125 (2000).

${ }^{176}$ See Ann Bartow, Electrifying Copyright Norms and Making Cyberspace More Like a Book, 48 VILL. L. REV. 13, 110-18 (2003).

${ }^{177}$ See Random House, Inc. v. Rosetta Books LLC, 150 F. Supp. $2 d 613$ (S.D.N.Y. 2001) (denying a motion for preliminary injunction brought by a book publisher authorized to publish novel "in book form" against electronic "book" publisher distributing same novel in electronic form), aff'd, 283 F.3d 490 (2d Cir. 2002).
} 
Similar questions have arisen even more recently in the context of Google's ambitious proposal to create a searchable digital archive that contains the entirety of the collections of some this country's largest academic libraries. This is Google Book Search. To the extent that publishers of copyrighted works in these collections object to the digitization without their authorization, the project faces some important challenges under copyright law. Google appears to be making millions of unauthorized "copies" of copyrighted works without the permission of the copyright owners. Or, perhaps Google is engaged in the application of the fair use doctrine at a scale never before imagined in human history. Google is, in a sense, a $21^{\text {st }}$ century digital extension of the university and of the library, making knowledge accessible and interpretable on a scale never before attempted, but uniquely suited to the new networked international cultural community.

Which is it? Here, even more starkly than with "new use" and "new technology" problems posed by electronic books, we benefit not only from thinking about what kind of narrative helps put the various pieces and places into some kind of coherent scheme, but also from thinking about what it means for a library to house "a book"as opposed to (or in addition to) a warehouse of the information that those books contain. Importantly, and to connect this theme to the first two, "books" are both objects, and metaphors.

\section{On Place and Space ${ }^{178}$}

A different, or perhaps supplemental, way to look at the Google Book Search example is to recover the physicalist metaphor that Radin, among others, largely rejects. To its defenders, Google Book Search appeals partly to our collective sense that libraries exist to organize and distribute information for public benefit, so that Google - which might be characterized as organizing and distributing that information on a massive scale - is simply stepping into the librarians' shoes. Yet libraries are places and spaces as much as they are domains of intellectual activity. Sociologists and geographers are acutely aware of the role of place and its cousin, space, in ordering human behavior. ${ }^{179}$ Individuals want and need to know where they are, and where others are, in order to manage various communicative practices. ${ }^{180}$ This relationship flows in the opposite direction as well. Critical geographers point out that places derive their character from the social practices situated there. ${ }^{181}$ Place and space structure social relationships, and are structured by them.

\footnotetext{
${ }^{178}$ The material in this Section is drawn in part from Michael J. Madison, Rights of Access and the Shape of the Internet, 44 B.C. L. REV. 433 (2003) [hereinafter Madison, Rights of Access].

${ }^{179}$ There is a vast literature on how various attributes of place and space, including distance, "adjacence," and permanence, support and instantiate social relations. See, e.g., William J. Mitchell, City of Bits: Space, Place and the Infobahn (1995); Jerry Frug, The Geography of Community, 48 StAn. L. REV. 1047 (1996); Thomas Gieryn, A Space for Place in Sociology, 26 AnN. Rev. Soc. 463, 463-96 (2000).

${ }^{180}$ See, e.g., Edward T. HALl, The HidDEn DimEnsion (1966) (describing the social use of space as the practice of "proxemics," borrowing from "proximity" as the most important social feature of space).

${ }^{181}$ See Michel de Certeau, The Practice of Everyday Life (Steven Rendall trans., Univ. of Cal. Press 1988) (1984); DAVID HARVEY, SPACES OF CAPITAL: TOWARDS A CRITICAL GeOgraphy (2001); Rosemary J. Coombe, The Cultural Life of Things: Anthropological
} 
In the physical world, Jane Jacobs, Lewis Mumford, and others pointed out long ago the extent to which we take space and place for granted, and the extent to which - resisting that sense-we can manage our environment to produce and support different kinds of social interaction. ${ }^{182}$ Architects and planners can do this through design. Law, too, can do it by rewarding features of the physical environment that signal the presence of bounded places. ${ }^{183}$ The urban planner Kevin Lynch demonstrated this in The Image of the City, ${ }^{184}$ concluding that inhabitants of a city relied on mental "readings" of their cities, focusing on landmarks and boundaries: "[I]f the environment is visibly organized and sharply identified, then the citizen can inform it with his own meanings and connections. Then it will become a true place, remarkable and unmistakable."185 Lynch used his subjects' reactions to the delineation of their environments as measures of "imageability," defined as "that quality in a physical object which gives it a high probability of evoking a strong image in any given observer. It is that shape, color, or arrangement which facilitates the making of vividly identified, powerfully structured, highly useful mental images of the environment."186 An "imageable" city conveys a coherent mental map to its inhabitants. ${ }^{187}$ Place is not simply a matter of where you are. Place and space are cognitive constructs.

When the question is how to develop a sense of what Radin might call a metaphorical legal neighborhood, or what we might call legal urbanity, the same lessons apply. The environmental heterogeneity and salience that Jacobs and Mumford praised, and the "imageability" that Lynch described, can be developed in legal contexts. How do we trade commodity against object, or recognize free speech or unfair competition law as domains that are adjacent to property law? Radin, like other scholars, is skeptical of the use of place and space metaphors in legal analysis. But we argue that those resources can be turned to our advantage. The apparent "physical" features of an online setting may be sufficiently stable to signify "place" to the individuals who "go" and "stay" there. With objects, the law might affirm the salience of the "good" objects and lessen the salience (and heighten the relational character) of the bad.

Law has the tools for this exercise, which we can use to reward "imageability." Online, for example, boundaries, borders, and connections in computer networks may be omnipresent as a technical matter but hidden, for all intents and purposes,

Approaches to Law and Society in Conditions of Globalization, 10 AM. U. J. INT'L L. \& PoL'Y 791 (1995).

${ }^{182}$ See generally Jane Jacobs, The DeAth AND Life of Great American Cities (1961); Lewis Mumford, The City in History: Its Origins, Its Transformations, and ITS Prospects (1961); see also Joseph Rykwert, The Seduction of Place: The City in the Twenty-First CENTURy (2000).

${ }^{183}$ See First Unitarian Church of Salt Lake City v. Salt Lake City Corp., 308 F.3d 1114, 1121 (10th Cir. 2002); Hotel Employees \& Rest. Employees Union Local 100 v. City of N.Y. Dep't of Parks \& Recreation, 311 F.3d 534, 544 (2d Cir. 2002).

${ }^{184}$ Kevin Lynch, The Image of the City 2, 8-13 (1960).

${ }^{185}$ See id. at 92 (emphasis omitted).

${ }^{186} I d$. at 9.

${ }^{187}$ See id. at $108-10$. 
from the perspective of those who use those networks. Law and policy may intervene to promote (or lessen) the salience of those boundaries and borders in a variety of doctrinal settings. Purported acceptances of offers of clickwrap agreements and "terms of use" may be deemed ineffective if offers are not sufficiently visible. ${ }^{188}$ "Technological protection measures" that trigger application of the anti-circumvention provisions of the Digital Millennium Copyright Act may be deemed "ineffective" if the user is not sufficiently warned of their existence. ${ }^{189}$ In property law, it might be argued that the doctrine of "trespass to chattels" may not be invoked by the owner of an online data resource unless the boundary that the defendant has crossed is marked in some clear, human-readable way. ${ }^{190}$

\section{E. On Convention, Pattern, and Practice ${ }^{191}$}

Among the socially-constructed recourses at our metaphorical disposal here are social phenomena themselves. We experience the world not only in terms of the language that we use, the stories that we tell, the objects that we make and find, and the places that we inhabit, but in terms of the social organization that we build. A fifth tool that we might explore in elaborating and supplementing Radin's relational analysis is the study of groups, and more precisely, the study of social practices and disciplines.

This is a difficult concept to capture briefly, since so much has been written by so many and from a broad variety of perspectives. In a recent article on fair use in copyright law, one of us analyzed economic, sociological, cultural and anthropological literature and concluded that the law can effectively query patterns of social behavior oriented around particular disciplines or practices, such as journalism, or scholarship. In turn, those patterns may serve as stable referents for applying the notoriously elusive "fair use" concept. But while we are guided by the belief that that each of these bodies of literature is ultimately talking about the same subject, that sense is more tentative than firm.

Disciplines, for example, come with sets of rules. Those are soft rules, to be sure, but typically rules that are recognized both inside and outside the discipline and that police the borders of the discipline and activity by its members. Professional disciplines are not the only sources of rules. Rules can be borrowed from outside contexts, or they can emerge from sustained interaction among individuals. They may be formal; they may consist of social norms; and/or they may consist of conventions or regularities in social behavior. Among other things, this echoes the notion of "fields" of practice proposed by the French sociologist Pierre Bourdieu, who offered the idea of the habitus to define the formal and informal processes - the

\footnotetext{
${ }^{188}$ See Specht v. Netscape Comm’s Corp., 306 F.3d 17 (2d Cir. 2002).
}

${ }^{189}$ See Lexmark Int'l, Inc. v. Static Control Components, Inc., 387 F.3d 522, 546-47 (6th Cir. 2004); Chamberlain Group Inc. v. Skylink Technologies, Inc., 381 F.3d 1178, 1200-01 (Fed. Cir. 2004). The relevant warning may be modest, as in the clickwrap agreement that the court relied on in Davidson \& Associates v. Jung, 422 F.3d 630 (8th Cir. 2005).

${ }^{190}$ See Madison, Rights of Access, supra note 178, at 492-502.

${ }^{191}$ See Madison, supra note 132, at 1628-29; Michael J. Madison, Social Software, Groups, and Governance, MicH. ST. L. REV. (forthcoming 2006) [hereinafter Madison, Social Software]. 
knowledge base, the internalized codes of thought and action, and manners of thought, or in sum, the feel for how things are done, or the activities and concepts that both unify and produce practices and representations-that constrain action within a given domain. ${ }^{192}$

Equally helpful analytic resources here include the broad concepts of the institution, which encompasses individuals, groups, relationships, and cognitive schemes and frames for constructing them; ${ }^{193}$ the community of practice, groups of individuals united informally by shared normative expectations, habits, customs, and group identity ${ }^{194}$ and "practice" itself, defined as a shared but informal set of practical understandings, with a normative component, embedded in social structures. ${ }^{195}$ The underlying point is that the existence and content of a given pattern cannot be determined entirely or even primarily within the analytic framework supplied by legal doctrine itself. The tool here is part of a broader theoretical approach that situates the foundations of stable law largely in social conventions rather than solely in legal institutions. ${ }^{196}$

The common issue is the extent of limitations on discretionary behavior within a specified social or cultural network, limitations that might be internalized via socialization or professional training, or that might be imposed externally via

${ }^{192}$ See generally Pierre Bourdieu, Distinction: A Social CritiQue of the Judgement of Taste (Richard Nice trans., 1984); Pierre Bourdieu, The Logic of Practice (Richard Nice trans., Stanford Univ. Press 1990).

${ }^{193}$ See Roger Friedland \& Robert R. Alford, Bringing Society Back In: Symbols, Practices, and Institutional Contradictions, in THE New Institutionalism IN ORganizational ANALYsis 232-63 (Walter W. Powell \& Paul DiMaggio eds., 1991); Ronald L. Jepperson, Institutions, Institutional Effects, and Institutionalism, in THE NEW INSTITUTIONALISM IN ORGANIZATIONAL ANALYSIS, supra, at 143-63.

${ }^{194}$ See Jean Lave \& Etienne Wenger, Situated Learning: Legitimate Peripheral PARTicipation 98 (Roy Pea \& John Seely Brown eds., 1991) (defining "community of practice [a]s a set of relations among persons, activity, and world, over time and in relation with other tangential and overlapping communities of practice. . . . [I]t provides the interpretive support necessary for making sense of its heritage"); see also Thomas C. Grey, What Good Is Legal Pragmatism?, in Pragmatism in LAW AND Society 9, 12 (1991) ("[T]hought always comes embodied in practices-culturally embedded habits and patterns of expectations, behavior, and response.").

${ }^{195}$ See David Stern, The Practical Turn, in The Blackwell Guide to the Philosophy of Social SCIENCES 185 (Stephen P. Turner \& Paul A. Roth eds., 2003) (characterizing practice theory as paying close attention to particular practices and the context in which they are located); Theodore R. Schatzki, Introduction: Practice Theory, in THE PRACTICE TURN IN CONTEMPORARY THEORY 1, 2-4 (Theodore R. Schatzki et al. eds., 2001).

${ }^{196}$ See, e.g., LON L. Fuller, Human Interaction and the Law, in The PrinciPles OF SOCIAL ORder: SElected EsSAYS OF LON L. Fuller 211 (Kenneth I. Winston ed., 1981); see also Gerald J. Postema, Conventions in Law, in 1 The New Palgrave Dictionary of ECONOMICS AND THE LAW 466-67 (Peter Newman ed., 1998) (describing social conventions as regularized manifestations of social patterns defined by mutual expectations and interest in solving coordination problems and serving as part of the foundation of law). The best-known account of social conventions posits an account of conventions as coordination equilibria for rational individuals. See David K. Lewis, Convention: A Philosophical Study 14-23 (1969). 
participation in the pattern, or both. Social "norms" as guides to individual behavior are relevant, but they are neither the necessary beginning nor the end of the question. A social or cultural pattern may be defined by informal expectations, customs, and habits, by norms, by more formal organizations, institutions, or hierarchies, by communications and coordination networks, or by a combination of these. ${ }^{197}$ Relevant evidence may consist of individual practices and behaviors themselves, structures of formal and informal groups, and descriptions of cognitive structures, such as schemata and scripts. ${ }^{198}$ Evidence may be purely contemporary, or it may incorporate history and tradition.

We should make explicit that a "disciplinary" tool accepts at least the possibility of group agency alongside traditional accounts of individual agency. At the very least, the two perspectives need to be accounted for. Anthony Giddens does so with his "structuration" thesis, positing that individuals (particular actions) and groups (rules) are functionally inseparable because they are in the ongoing process of simultaneously constructing each other. ${ }^{199}$ Intentionality is contextual, making social groups and structures an inherent part of social analysis. Mark Johnson explains this point in terms that crystallizes the social practices perspective and connects it to the frameworks above that are based more explicitly on metaphor and cognition:

[A]ny statements we make, any directives we give, any rules we lay down are applicable, not because the concepts specify their own determinate conditions of satisfaction, but rather because we understand these concepts and rules relative to shared idealized cognitive models, scripts, and narratives that are tied to embodied experiences, communal histories, practices, and values. The rules can work, when they work, precisely because of these framing cognitive models and practices. They are not ... merely non-propositional, non-semantic background assumptions. Rather, they are part of our conceptual apparatus by which we make sense of and act purposively within concrete situations. ${ }^{200}$

How might we make use of this method in approaching the underlying question of commodities and objects? How do social practices illuminate the relational character of that question? One example is patent law. Scholars looking at the sociology of science have recognized that the optimal organization of scientific research consists of independent communities of researchers working with knowledge of one another's activities. ${ }^{201}$ Welfare costs from duplicative research are

\footnotetext{
${ }^{197}$ See Steven A. Hetcher, Norm Proselytizers Create a Privacy Entitlement in Cyberspace, 16 BERKELEY TECH. L.J. 877, 892 n.53 (2001) (adopting a definition of "norm" that is comparable, descriptively, to my use of "pattern"). $C f$. W. Richard SCOTt, INSTITUTIONS AND ORGANIZATIONS 33 (1995) (defining institutions as cognitive, normative, and regulative structures and activities).

${ }^{198}$ See Roger C. Schank \& Robert P. Abelson, Scripts, Plans, Goals and Understanding: AN INQUiRY INTO Human KNOWLEDGE STRUCTURES 36-68, 222-37 (1977).

199 See Anthony Giddens, The Constitution of Society: Outline of the Theory of STRUCTURATION 162 (1984).

${ }^{200}$ Mark Johnson, Law Incarnate, 67 BROOK. L. REV. 949, 957 (2002).

${ }^{201}$ See Rebecca S. Eisenberg, Patents and the Progress of Science: Exclusive Rights and Experimental Use, 56 U. CHI. L. REV. 1017, 1061, 1063-65 (1989) (citing Michael Polanyi,
} 
more than offset by correction of mistakes, confirmation of research results, and differential analyses of common data, leading to better syntheses. ${ }^{202}$ Pure "science," in turn, receives special dispensations in intellectual property law. "Laws of nature" (the objects of basic scientific research) are unpatentable. Until recently, academic practitioners of patented technology could look to an "experimental use" exemption from liability for patent infringement. Measuring what is "basic" and therefore unpatentable is a disciplinary problem; like most patent law metrics, the issue is framed in terms of the understanding of a hypothetical "Person Having Ordinary Skill in the Art." What is in and what is out, in other words, is explicitly a question of disciplinary understanding. The experimental use doctrine shows how disciplinary bulwarks that historically have protected the public domain from propertization may evolve as the discipline itself evolves. The Federal Circuit appears to have cut back the experimental use exception dramatically, on the rationale that university-based research are no longer presumptively entitled to rely on characterization by reference to a disciplinary understanding of "basic science," 203 and therefore should not presume that university-based research is not subject to ordinary rules of patent infringement.

Disciplinary practices and normative communities are, in part, sorts of narratives, and we connect them explicitly to metaphor and to the cognitive basis for using language-based tools. Disciplines and practices are frequently if not necessarily grounded in space and time, and equally frequently they are organized around objects and other things. ${ }^{204}$ This perspective, like the four previously reviewed, is not perfectly independent of any other. But social practices do have power in themselves, not merely by virtue of the stories we tell about them, or that their members tells about themselves, and they are sources of norms and sources of commitment that the law can borrow to articulate relational understandings of property interests more robust.

\section{CONCLUSION}

What we have tried to do in this Comment is give a sense of the variety of approaches and tools that both practitioners and theorists of the law might explore in tackling some of the difficult issues of property and related theory that Margaret Radin points to. The relational approach to those problems can be more effectively analyzed if we embrace, rather than exclude, metaphorical, conceptual, and experiential methods. We have suggested some of those methods here. There are others, and there are blends and refinements to what we have presented.

The Republic of Science: Its Political and Economic Theory, 1 Minerva 54, 56 (1962) and the various works of Robert K. Merton and Warren O. Hagstrom).

${ }^{202}$ Robert Merton famously described "science" according to its norms of information disclosure and exchange. See Robert K. Merton, The Normative Structure of Science, reprinted in The Sociology of ScIENCE: TheORETICAL AND EMPIRICAL InVESTIGATIONS 267, 270-75 (Norman W. Storer ed., 1973); see also Stephen Hilgartner \& Sherry Brandt-Rauf, Data Access, Ownership, and Control: Toward Empirical Studies of Access Practices, 15 KNOWLEDGE 355 (1994) (describing "datastreams" model of scientific research and information exchange).

${ }^{203}$ See Madey v. Duke Univ., 307 F.3d 1351, 1360-61 (Fed. Cir. 2002).

${ }^{204}$ Madison, Social Software, supra note 191. 
We close with a final observation. Perhaps a more effective metaphor for the whole analysis is not a neighborhood in the context of a city, as Radin suggests, but a network. Rather than drawing a suitable balance in terms of the salience and the permeability of boundaries between disciplines and between doctrinal signposts within disciplines, perhaps we should think of law as a network to be interpreted. ${ }^{205}$ The notion of a network preserves a relational, metaphoric dynamism and also permits positive objectification. The task is to know where and when and how to identify nodes in the network, and to articulate connections and dependencies between and among them. The task is also to understand that these nodes and connections are constructs that can and perhaps should change. The hermeneutic task here might be compared to that of an architect or designer trying to bring sense to the signs that the human world presents. ${ }^{206}$ What Radin brings and has brought to property law and to legal theory in general is an unfailing embrace of the multiplicity of disciplines that bear on particular problems. What we want to do here is celebrate this facet of her work, and suggest how to advance her critique a bit beyond even where she has taken it so far. We hope that the methods we suggest, taken in tandem with Radin's observations about the dynamism of our culture and economy, offer some thought-provoking and potentially useful avenues for research and application.

\footnotetext{
${ }^{205}$ We thus propose a broadening and deepening of the network metaphor that Edward Rubin develops for government and governance. See supra text accompanying notes 141-42.

${ }^{206}$ Steven Johnson describes a comparable question of design in STEVEN JOHNSON, Interface Culture: How New Technology Transforms the Way We Create and COMMUNICATE 11-14 (1997), in which he relates sign problems and design in medieval architecture, nineteenth-century literature, and software interfaces.
} 